CUADERNOS DE ESTUDIOS GALLEGOS, LXII Núm. 128 (enero-diciembre 2015), págs. 13-46

ISSN: 0210-847X

DOI: 10.3989/ceg.2015.128.01

\title{
«FAZER CAVALEIROS»: \\ AS CERIMÓNIAS DE INVESTIDURA CAVALEIRESCA NO PORTUGAL MEDIEVAL (SÉCULOS XII-XV)
}

Miguel Aguiar

Faculdade de Letras da Universidade do Porto 


\section{«FAZER CAVALEIROS»: AS CERIMÓNIAS DE INVESTIDURA CAVALEIRESCA NO PORTUGAL MEDIEVAL (SÉCULOS XII-XV)}

Resumo

Um cavaleiro não nascia cavaleiro: fazia-se. Por essa razão, a investidura ou adubamento tornou-se um evento de capital importância. Este artigo pretende analisar tal cerimónia sob dois prismas. Começar-se-á por tentar perceber os significados que ela foi assumindo ao longo do período cronológico definido. Na segunda parte, analisa-se o ritual propriamente dito, tentando descrevê-lo e procurando compreender a simbologia que lhe estava associada. Para cumprir estes propósitos cruzam-se diferentes tipologias de fontes: crónicas, livros de linhagens, obras de cariz legislativo e tratadístico, recorrendo-se ainda a documentação de carácter diplomático. Ao longo do texto procurar-se-á manter uma perspetiva comparativa com outras realidades peninsulares, não perdendo também de vista o que entretanto se passava nos territórios além-Pirenéus.

PALAVRAS ChAVE: cavaleiros; cavalaria; investidura; adubamento

\section{«FAZER CAVALEIROS»: LAS CEREMONIAS DE INVESTIDURA CABALLERESCA EN EL PORTUGAL MEDIEVAL (SIGLOS XII-XV)}

\section{RESUMEN}

Un caballero no nacía caballero: se hacía en uno. Por esa misma razón, la investidura o adubamento tomó desde muy pronto una importancia crucial. Este artigo pretende analizar esta ceremonia en dos puntos de vista. Empezaremos por tratar de entender los significados que la misma ha asumido al largo del tiempo definido. En la segunda parte, se analiza el ritual, intentando describirlo y buscando comprender la simbología que le estaba asociada. Para lograr estos objetivos se mezclan diferentes tipologías de fuentes: crónicas, livros de linhagens, obras de naturaleza legislativa y tratadística, recorriendo aún así a documentación de carácter diplomático. Al largo del texto, se buscará mantener una perspectiva comparativa con otras realidades peninsulares, no olvidando también lo que se pasaba en los territorios más allá de los Pirineos.

Palabras Clave: caballeros; caballería; investidura; adubamento

$$
\begin{gathered}
\text { «FAZER CAVALEIROS»: THE CEREMONIES OF DUBBING TO KNIGHTHOOD IN } \\
\text { MEDIEVAL PORTUGAL (12-15 TH CENTURIES) }
\end{gathered}
$$

\section{ABstract}

The ritual of dubbing to knighthood assumed since an early stage a capital importance, given that it was the necessary step to become a knight. This article will focus on this ceremony, dividing its analysis in two main parts. First, it will try to understand the different meanings of the ritual on the selected period. On the second part, the aim is to focus on the ritual itself, trying to describe how it was processed and analyzing the simbology of each step. As sources, this study uses chronicles, genealogical literature, legislative compilations, chivalric treatises and diplomatic documents. Throughout the text, there will be a comparative view with the rest of the Iberian kingdoms and also with other European regions.

KEY WORDS: knight; knighthood; chivalry, dubbing 
Recibido/Received: 06/05/2015

Aceptado/Accepted: 27/07/2015

cavalaria continua a ser um objeto de estudo fascinante, merecedor da
atenção de muitos historiadores europeus e americanos. Sendo quase
sempre um tema que cativa os seus investigadores pelo lugar que ocupa no imaginário das sociedades ocidentais, é importante começar por referir que, de quase todas as práticas que lhe estão associadas, a investidura é talvez a mais simbólica. É natural que assim seja: afinal de contas, temos a ideia pré-concebida de que se tratava do momento em que o jovem escudeiro era investido numa categoria superior, imbuída de uma ideologia própria dos grupos dominantes. Esta imagem, porém, necessita ser matizada.

As dificuldades para levar a cabo um estudo deste género surgem desde logo no momento de definir a terminologia operativa. Contrariamente às línguas francesa e inglesa, que desde cedo consagraram verbos específicos para estas cerimónias (adouber e dubbing), as fontes portuguesas utilizam expressões como «fazer» ou «armar cavaleiros». De facto, não encontramos palavras como investidura ou adubamento; ainda assim, e por uma questão prática, também utilizarei esses termos ao longo do texto para me referir ao objeto deste artigo. Apesar de tudo, creio que eles se encaixam no sentido da cerimónia, dado que ela implicava uma elevação, a receção de poderes e de deveres. Enfim, tinha o condão de entronizar o indivíduo num determinado estatuto. De resto, a palavra investidura já tinha sido utilizada até por historiadores espanhóis ${ }^{1}$. Quanto a adubamento, trata-se de uma adaptação do verbo francês $a d o u b e r^{2}$, e embora também não conste nas fontes portuguesas, optei por utilizar esta expressão pois traduz o sentido das práticas aqui analisadas ${ }^{3}$.

\footnotetext{
1 Bernabé Martínez Ruzz, "La Investidura de Armas en Castilla", Cuadernos de Historia de España, vol. I-II (1944), págs. 190-221; Bonifacio Palacios Martín, "Investidura de Armas de los Reyes Españoles en los siglos XII y XIII", Gladius, Actas do I Simpósio Las Armas en la Historia (siglos X-XIV), volume especial, (1988), págs. 153-192.

2 Jean FlorI, "Sémantique et société medieval. Le verbe adouber et son évolution au XIIe siècle". Annales. Économies, Sociétés, Civilisations, 5 (1976), págs. 915-940.

3 Como já havia feito João Gouveia MonteIro em A Guerra em Portugal no Final da Idade Média, Lisboa, Notícias, 1998, págs. 490-491.
} 
Tal como quase tudo o que respeita à cavalaria em Portugal, as cerimónias de investidura nunca mereceram um tratamento sistemático ${ }^{4}$. É também verdade que as opções metodológicas para abordar este problema estão em certa medida condicionadas pelos vestígios que chegaram até nós. Neste sentido, convém assinalar que os testemunhos empurram tendencialmente o investigador para os séculos finais da Idade Média. Para períodos anteriores ao século XIV existem poucas notícias de adubamentos, sendo que uma boa parte delas sobreviveu em textos significativamente posteriores ao tempo dos personagens a que se reportam.

Considerando o quadro traçado, a estratégia metodológica passou fundamentalmente por recolher o maior número de notícias possível e por cruzar diferentes tipologias de fontes, que importa caracterizar sumariamente. Desde logo, as 'literárias': os Livros de Linhagens ${ }^{5}$, de onde se retiram várias notícias de indivíduos «feitos cavaleiros»; e as crónicas, onde por vezes com maior riqueza descritiva surgem relatos de investiduras, de homens «feitos» ou «armados cavaleiros». As obras legislativas e tratadísticas têm também grande importância. Refletem a tentativa de impor critérios mais restritivos à realização da investidura cavaleiresca ${ }^{6}$, expõem como é que esta se devia processar, e deixam entrever as influências que estão na raiz dos textos. No século XV, as Ordenações Afonsinas descreveriam com acuidade os passos do rito e a sua simbologia ${ }^{7}$. Esta síntese, praticamente

\footnotetext{
${ }^{4}$ Alguns trabalhos salientam o caráter tardio das fontes que mencionam os ritos de investidura: A. H. de Oliveira Marques, "Cavalaria", em Dicionário de História de Portugal, (dir.) Joel Serrão, Livraria Figueirinhas, vol. II, págs. 26-28; José MatToso, "Cavalaria", em Dicionário Ilustrado de História de Portugal, José da Costa Pereira (coord.), Lisboa, Alfa, 1985, pág. 116 e "Cavalaria" (1), em Dicionário da Literatura Medieval Galega e Portuguesa, Giulia Lanciani e Giuseppe Tavani (org.), Lisboa, Caminho, 1993, págs. 152-154. João Gouveia Monteiro analisou brevemente o significado do ritual no final da Idade Média: João Gouveia Monteiro, A Guerra em Portugal no Final da Idade Média..., págs. 490-491. Pelo contrário, no panorama além-Pirenéus o assunto já foi amplamente estudado e continua a merecer visões renovadas e acesos debates. Citem-se, a título de exemplo, os seguintes trabalhos: Jean FLORI, "Sémantique et société medieval. Le verbe adouber et son évolution au XIIe siècle" e L'Essor de la Chevalerie, Genève, Droz, 1986; Maurice Keen, Chivalry, Yale, University Press, 2005 ( $1^{\text {a }}$ edição de 1984), págs. 64-82; Fionn PilBrow, "The Knigths of the Bath: Dubbing to Knighthood in Lancastrian and Yorkist England" em Heraldry, Pageantry and Social Display in Medieval England, Peter Cross e Maurice Keen (eds.), Boydell, 2002, págs. 195-218; Katie Stevenson, Chivalry and the practices of Knighthood in Scotland, 1421-1513, Cambdrige, University Press, 2006, págs. 41-60; Dominique Barthélemy, La Chevalerie, Paris, Fayard, 2007.

5 Livro de Linhagens do Conde D. Pedro, José Mattoso (ed.), Lisboa, Academia das Ciências, 1980 = de agora em diante LL; Livros Velhos de Linhagens: Livro Velho de Linhagens e Livro do Deão, J. Piel e José Mattoso (eds.), Lisboa, Academia das Ciências, $1980=$ de agora em diante $L V$ ou $L D$. 6 Livro das Leis e Posturas, Lisboa, Faculdade de Direito da Universidade de Lisboa, 1971, págs. 202-203.

7 Ordenações Afonsinas, fac-simile da edição feita na Real Imprensa da Universidade de Coimbra em 1792, Lisboa, Fundação Calouste Gulbenkian, 1998, título LXIII, págs. 368-372 = de agora em diante $O A$.
} 
copiada da Segunda Partida ${ }^{8}$, denuncia também em que medida estes documentos partilhavam ideias já explanadas em obras tratadísticas, e que enfatizavam justamente a relevância dos ritos de investidura. Um exemplo dessas obras, escrita no século XIII e em contexto hispânico, é o Livro da Ordem de Cavalaria, da autoria de Raimundo Llull'. No século XV, em Portugal, o Infante D. João, membro da Ínclita Geração, também se pronunciaria acerca do momento ideal para receber a cavalaria ${ }^{10}$. Por último, mas não menos relevantes, as fontes diplomáticas, e em particular os documentos provenientes da chancelaria régia, podem por vezes dar notícia de um indivíduo ter sido armado cavaleiro em certo momento da sua vida. Simultaneamente, essas referências permitem que se deduza o valor efetivo do adubamento, sobretudo no plano jurídico.

Descritas as condições em que se estrutura o presente estudo, começar-se-á por analisar a questão do significado da cerimónia, examinando-se posteriormente o ritual propriamente dito.

\section{O SIGNIFICADO DA CERIMÓNIA}

Maurice Keen considerou que a investidura cavaleiresca resultava principalmente da fusão de antigos rituais germânicos com elementos cristãos ${ }^{11}$. Eis, por um lado, o caráter prático, de entrega de armas e promoção à idade adulta, tal como Tácito havia observado nas tribos germânicas ${ }^{12}$. Por outro, denotam-se preocupações religiosas da parte dos cavaleiros, imbuídos de uma missão específica no ordenamento político da sociedade, ao mesmo tempo que se assiste a uma tentativa da Igreja em sacralizar os elementos da cavalaria. Esta interpretação global é comummente aceite pela historiografia que se dedica a esta temática, embora os investigadores discordem frequentemente no que toca à problemática das origens ${ }^{13}$.

8 Partida Segunda de Alfonso X El Sabio, Manuscrito 12794 de la BN, Aurora Juárez Blanquer e Antonio Rubio Flores (eds.), Granada, Impredisur, Título XXI, págs. 184-187= de agora em diante PII.

9 Raimundo Llull, Livro da Ordem de Cavalaria, Artur Guerra (ed.), Lisboa, Assírio e Alvim, 2012. Para uma visão global acerca deste personagem e da sua obra ver Martin Aurell, "Chevaliers et chevalerie chez Raymond Lulle". Cahiers de Fanjeaux: Collection d'Histoire religieuse du Languedoc au XII et au début du XIV siècle, 22 (1987) págs. 141-157.

${ }^{10}$ Livro dos Conselhos de el-rei D. Duarte, João José Alves Dias, A. H. de Oliveira Marques e Teresa Rodrigues (eds.), Lisboa, Estampa, 1982, págs. 43-49.

${ }^{11}$ Maurice KeEn, Chivalry..., págs. 64-66; Richard BArber, The Knight and Chivalry, Woodbridge, Boydell, 1995, págs. 23-27.

12 TÁcito, La Germanie, Jacques Perret (ed.), Paris, Société d’Édition Les Belles Lettres”, 1983, págs. $78-80$.

${ }^{13}$ Continua a ser difícil - e provavelmente será impossível - datar com exatidão o momento em que surgem efetivamente investiduras de tipo cavaleiresco. A posição de Jean Flori no já citado artigo "Sémantique et société medieval. Le verbe adouber et son évolution au XIIe siècle" foi revista por 
Ainda assim, e para o que de momento nos interessa - os rituais de investidura no espaço português - é importante não ficar refém de enquadramentos teóricos formulados para realidades exógenas, sendo preferível apostar numa abordagem empírica, que reflita acerca do que é possível extrair da documentação portuguesa. Uma primeira abordagem global às notícias de adubamentos recolhidas parece destacar um intuito sobretudo promocional e prático das cerimónias. Mas é uma vocação funcional que se divide em pelo menos duas versões, reflexo da evolução da cavalaria no Ocidente Peninsular. Em primeiro lugar, fizeramse investiduras no sentido de promover um homem ao estatuto de cavaleiro: fosse ele proveniente de um estrato não-nobre, ou fosse apenas um escudeiro à procura de subir na hierarquia social e honorífica. Estas cerimónias seriam dirigidas fundamentalmente àqueles que nos diplomas régios nos aparecem como cavaleiros, tratando-se de homens pertencentes, pelo menos desde finais do século XII e inícios do XIII, à base do grupo aristocrático ${ }^{14}$. Ainda assim, convém referir que se mantém ao longo de toda a Idade Média portuguesa um certo hibridismo entre as camadas 'populares' e aristocráticas ${ }^{15}$, sendo por vezes difícil deslindar o estatuto social dos indivíduos, em particular quando se trata de escudeiros e cavaleiros. Este fenómeno é ainda mais acentuado no século $\mathrm{XV}$, quando a constituição de grandes casas senhoriais suscitou a formação de redes clientelares e vassálicas extensas ${ }^{16}$, e quando a guerra permanente em África abriu portas à nobilitação dos que desejavam melhorar a sua condição através das armas.

Existia ainda o adubamento que tinha como intenção promover um homem ao estado cavaleiresco, intuito algo distinto do anterior uma vez que nestes casos pesam sobretudo aspetos honoríficos e ideológicos. No entanto, em Portugal, o triunfo da conceção honorífica da cavalaria, com os seus ideais, práticas e

outros autores, nomeadamente Dominique BARTHÉLEMY. Deste autor, veja-se o artigo "Adoubement et chevalerie dans les chansons de Roland et d'Aspremont", em Lênia Márcia Mongelli (dir.), De Cavaleiros e Cavalarias: por terras de Europa e Américas, São Paulo, Humanitas, 2012, págs. 179189 e também La Chevalerie, Paris, Fayard, 2007, págs. 213-228, 299-306 e 426-431.

${ }_{14}$ José Mattoso, Ricos-homens, Infanções e Cavaleiros, Lisboa, Guimarães Editores, 1985, págs. 171-178; "Os senhores", em José Mattoso (coord.), A Monarquia Feudal, vol. II da História de Portugal de José Mattoso (dir.), Lisboa, Estampa, 1997, págs. 149-150; Leontina Ventura, "Nobreza - da Guerra à Corte", em Maria Helena da Cruz Coelho e de Armando Luís de Carvalho Homem (coord.), Portugal em Definição de Fronteiras, vol. III da Nova História de Portugal de Joel Serrão e de A. H. de Oliveira Marques (dir.), Lisboa, Presença, 1996, pág. 218.

${ }^{15}$ Veja-se o artigo de Mário VIANA, "Os Cavaleiros de Santarém na segunda metade do Século XIII", em Categorias Sociais e Mobilidade Urbana na Baixa Idade Média, Lisboa, Colibri/CIDEHUS, 2012, págs. 61-81

${ }^{16}$ Mafalda Soares da CunHa, "A Nobreza Portugesa no início do Século XV: Renovação e Continuidade", Revista Portuguesa de História, XXXI: 2 (1996), págs. 219-252. 
mitologia próprias, ter-se-á construído lentamente ao longo do século XIII ${ }^{17}$. É apenas na centúria seguinte que se podem encontrar vestígios palpáveis para, com propriedade, considerar que a cavalaria era já uma ideia que congregava reis, pequenos e grandes aristocratas e até homens dos concelhos. Tanto quanto é possível apurar, a conceção clássica da cavalaria parece triunfar algo tardiamente em Portugal, mesmo em comparação com os vizinhos reinos peninsulares ${ }^{18}$. Este tipo de cerimónias, destinadas a promover um homem ao estado cavaleiresco, eram dirigidas àqueles que procuravam ser investidos não porque carecessem de ultrapassar tal ritual para melhorar a sua condição, mas sim porque pretendiam interpretar o código cavaleiresco como forma de vida. São, portanto, ocasiões consagradas principalmente aos monarcas e à alta aristocracia; mas, como se terá oportunidade de observar, não apenas a estes. Advirta-se, porém, que tal não quer dizer que não se dessem casos em que os novos cavaleiros, nobres de pequena dimensão ou vilões recém-promovidos, não sentissem convictamente os ideais cavaleirescos, fazendo destes valores o motor para adquirir uma posição mais favorável. Por motivos metodológicos, aceite-se a necessidade de estabelecer algumas divisões operatórias para construir uma visão compreensiva acerca desta matéria. Os critérios apresentados têm essa finalidade, não pretendendo ser demasiado exaustivos ou rígidos. Pelo contrário, dada a extensa cronologia do estudo, e até pelo exemplo mencionado, saliente-se a necessidade de abordar estas questões com alguma flexibilidade - até porque a própria terminologia aplicada nas fontes é muitas vezes de dúbia interpretação.

\section{a) As investiduras no estatuto de cavaleiro}

Como acima foi dito, trata-se aqui da investidura daqueles que usufruíam do estatuto legal de cavaleiro, com todas as dúvidas de interpretação que o termo aporta, e ainda que fossem mais ou menos observantes dos valores da cavalaria. De todos, talvez os casos mais percetíveis nas fontes se reportem àqueles que através da investidura cavaleiresca conseguiam aceder a um estatuto de nobreza. Ainda assim, e extravasando o contexto da cavalaria nobre, convém sublinhar

\footnotetext{
17 José Mattoso, Identificação de um País: ensaio sobre as origens de Portugal (1096-1325), vol. I, Oposição, $5^{a}$ edição, Lisboa, Estampa, 1995, págs. 117-125.

${ }^{18}$ Bonifacio Palacios Martín vê no reinado de Afonso VIII um momento capital na construção da ideologia cavaleiresca em Castela ("La recepcíon de los valores caballerescos por la monarquia castellano-leonesa", Codex Aquilarensis: cadernos de investigación del monasterio de Santa María la Real, 13 (1997/98), págs. 88-95). Jesús RodRígueZ VELASCO apresenta uma opinião um pouco diferente, enfatizando a importância do reinado de Afonso X enquanto momento de síntese de uma visão da cavalaria que congrega, por um lado, os múltiplos sentidos que a palavra assume na tradição ibérica e, por outro, uma dimensão honorífica e política que resultava sobretudo de influências transpirenaicas ("De oficio a estado. La caballería entre el Espéculo y las Siete Partidas", Cahiers de Linguistique Hispanique Médiévale, 18-19 (1993), págs. 49-77).
} 
que a própria cavalaria vilã teria os seus rituais específicos de promoção de um novo cavaleiro, certamente influenciados por ancestrais costumes ligados às terras, como demonstrou Luís Filipe Oliveira ${ }^{19}$. Todavia, tendo em atenção a cerimónia enquanto momento de promoção ao grupo aristocrático, atente-se ao exemplo de João Afonso de Goriz, conhecido através de um diploma emitido em 1424 pela Chancelaria de D. João I ${ }^{20}$. João Afonso acompanhou o Infante D. Henrique no socorro à guarnição de Ceuta. Como galardão, «elle foe fecto caualeyro em a nossa cidade de cepta per mãão do jffante dom anrrique». Tendo alguns bens em reguengos nos arredores de Lisboa, herdados da parte de sua mulher, receava agora perdê-los porque ouvira dizer que os cavaleiros não podiam ter propriedades em terras do rei. O monarca concede-lhe a ele e aos seus herdeiros a mercê de manterem o património. Contudo, o documento explicita claramente que, depois de ter servido o rei, João Afonso «guanhou honrra de caualaria» pela mão de D. Henrique e passou a usufruir de um estatuto de nobreza, que aliás punha em risco as suas posses.

A cerimónia de investidura tinha portanto o poder de elevar alguns homens ao estamento aristocrático, desde que estes se tivessem demonstrado valorosos no serviço aos seus senhores: reis, infantes ou grandes aristocratas. Na realidade, o caso de João Afonso de Goriz não é algo de isolado ${ }^{21}$.

A talvez desregrada concessão da cavalaria viria até a ser motivo de protestos nas Cortes de 1472-73. Suplicava-se ao rei que não permitisse a investidura de homens que não podiam manter tal condição. Pelo contrário, o desejável seria conservar uma posição rigorosa: os capitães em África apenas deviam elevar à

\footnotetext{
${ }^{19}$ Os casos de Arruda e de Alcanede, estudados por Luís Filipe Oliveira, talvez possam servir de exemplo. Os costumes da vila de Arruda estabeleciam que, no mês de Maio, aquele que quisesse ser cavaleiro devia apresentar-se sobre a sua montada perante as autoridades do concelho, dizendo que quer "ouyr e gouuyr dos vsos e foros e boons costumes e quero sser caualleiro". Depois, "diram os homeens boons e alcaide que ho am por caualleiro E sse nom ffor ffilho de caualleiro ha de pagar ao alcaide hüu par de framgõos e depois que os teuer ho alcaide emtom dira que lhe apraz de ser caualleiro". Apesar de estes costumes terem sido passados a escrito entre o final do século XIV e início do $\mathrm{XV}$, fruto de um diferendo relativo ao pagamento da jugada, creio que o ritual enunciado teria raízes muito antigas. Evocaria provavelmente as velhas tradições da cavalaria vilã da Estremadura, impulsionada no período da Reconquista. Em Luís Filipe Oliveira: "Os cavaleiros de Carneiro e a herança da cavalaria vilã na Estremadura. Os casos de Arruda e de Alcanede", Medievalista [em linha], 1 (2005), disponível em: <http://www2.fcsh.unl.pt/iem/medievalista/MEDIEVALISTA1/ medievalista-cavaleiros.htm > [Consulta: 10/10/2014].

${ }^{20}$ Descobrimentos Portugueses, João Martins da Silva Marques (ed.), Lisboa, Instituto Nacional de Investigação Científica, 1988, suplemento do vol. I, doc. 77, págs. 105-106.

${ }^{21}$ Também em 1481 D. João II decide agraciar João Garcês com carta de armas, recompensando os vinte e cinco anos de contínuos serviços, alguns dos quais em África, tendo estado presente na conquista de Alcácer, de Anafé - onde foi armado cavaleiro pelo infante D. Fernando -, Arzila e Tânger (ANTT, Chancelaria de D. João II, Livro II, fólio $157-1^{\circ}$ ).
} 
nobreza os que protagonizassem feitos excecionais. Na resposta, D. Afonso V concorda $^{22}$. Alguns anos mais tarde, D. João II mandava aos capitães das praças que não fizessem cavaleiros os que não fossem fidalgos. Se por acaso alguém protagonizasse um feito merecedor, e não fosse nobre, então que se escrevesse ao rei, sendo da sua graça aprovar ou não a elevação à cavalaria ${ }^{23}$.

Poder-se-ia argumentar que este é o contexto do século XV, tempo em que a cavalaria vivia o seu declínio. Todavia, esta não é apenas uma realidade dessa centúria. Apesar de ser uma época em que tais testemunhos são mais abundantes, quer pelo maior número de fontes, quer pela aparente fluidez social permitida pela manutenção da guerra no Norte de África ${ }^{24}$, existem sinais claros de que já há muito tempo que a cerimónia de adubamento permitia a elevação à nobreza, e de que se procurava de alguma forma restringir esta via de promoção. Em Leão, uma lei de Afonso IX estabelecia que «los hijos de los villanos pertenecientes a nuestro derecho, los padres de los cuales no fueron caballeros, ninguno non ose facerlos caballeros nin haberlos por caballeros $\rangle^{25}$. Fenómeno paralelo veio a acontecer em Portugal. Em 1305, uma lei de D. Dinis sublinhava que apenas ao rei e ao seu herdeiro cabia o poder de fazer novos cavaleiros ${ }^{26}$. Considerando o sentido de toda esta legislação, creio ser possível defender que o século XV terá sido essencialmente um período em que se amplificaram realidades já visíveis em centúrias anteriores.

Existiam também os adubamentos que materializavam o cursus honorum cavaleiresco, elevando um antigo escudeiro à categoria de cavaleiro. Ainda que nem sempre as fontes deem conta da realização da cerimónia, em certas situações é lícito supor que ela se tenha realizado. Diogo Lopes é retratado na Estoria de Dom Nuno Alvrez Pereyra como «hum bom e nobre escudeyro e despoys foy nobre

\footnotetext{
${ }^{22}$ Capítulos gerais transcritos e incluídos em anexo na tese de Diogo Dias, As Cortes de Leiria e Évora de 1472-73: Subsídios para a História Parlamentar Portuguesa, dissertação de mestrado apresentada à Universidade de Coimbra, Coimbra, 2014, págs. 110-111.

${ }_{23}$ Álvaro Lopes de Chaves, Livro de Apontamentos (1438-1489), Anastácia Mestrinho Salgado e Abílio José Salgado (eds.), Lisboa, Imprensa Nacional, 1983, págs. 170-171. Esta intenção estará na base das posteriores "cartas de cavaleiro". Sobre este assunto ver o artigo de Pedro de Brito, "As Cartas de Cavaleiro e Escudeiro nos Sécs. XV e XVI", Revista Lusófona de Genealogia e Heráldica, 1 (2006), págs. 207-230.

${ }^{24}$ Armindo de Sousa, "Nobres", em José Mattoso (coord.), A Monarquia Feudal, vol. II da História de Portugal de José Mattoso (dir.), Lisboa, Estampa, 1997, págs. 374-375.

${ }^{25}$ Cit. por Bernabé Martínez Ruiz, "La Investidura de Armas en Castilla...”, pág. 208. O mesmo autor refere ainda o Fuero de Navarra, cujos contornos são semelhantes: "nuil richombre o ningun cavero non sea osado de fer cavero al filho del villano et aqueyll que is feyto cavero en esta guisa, sapiendo que es fillo de villano, pierda el cavayllo et las armas et torne villano para toda a vida". 26 "nenhũu homem de conçelho nom pode seer cavaleiro nem aver honra de cavalaria senom per seu Rey ou per seu filho que há de peytar per seu mandado dElRey", em Livro das Leis e Posturas, págs. 202-203.
} 
cavalleyro ${ }^{27}$. Deduz-se, portanto, que terá sido investido algures pelos anos da crise de 1383-1385, numa cerimónia de que hoje não temos qualquer vestígio. Ilustre-se ainda este género de casos com uma passagem da Crónica do Conde D. Duarte de Meneses, onde se alude a um grupo de homens «que eram scudeyros delRey e ao dyante foram cavalleyros per seus merecimentos» ${ }^{28}$.

A lista dos cavaleiros feitos por D. João I em Aljubarrota (14 de Agosto de 1385) também se revela preciosa para tentar perceber em que medida a investidura tinha impacto no estatuto jurídico dos indivíduos ${ }^{29}$. Apesar de apenas se ter identificado uma referência ao mesmo nome em diplomas anteriores e posteriores à data da batalha, é possível tirar algumas conclusões. Antes da Batalha Real identificamse casos como o de Rodrigo Afonso Lobo, que nos surge em dois documentos de 1384 como «escudeiro vassalo de D. João» ${ }^{30}$. Em diplomas emitidos depois de Aljubarrota encontram-se outros indivíduos já reconhecidos como cavaleiros: uns apenas cavaleiros ${ }^{31}$, outros «cavaleiros vassalos do rei» ${ }^{32}$.

A única situação em que foi possível encontrar referências documentais anteriores e posteriores à batalha do campo de S. Jorge, serve como exemplo para as recorrentes dificuldades de interpretação quer dos documentos jurídicos, quer da cronística. Em Setembro de 1384, Antão Vasques, cavaleiro morador em Lisboa, recebe do Mestre de Avis o lugar de Unhos e a adega de Camarate. Este Antão Vasques é o mesmo «muy boõ cavaleiro e bem ardido e huu dos boõs homens darmas que o comde [Nuno Álvares Pereira] em sua companhia trazia» ${ }^{33}$, e que organizou uma cavalgada em Castela ${ }^{34}$. Mas o que parece estranho é o facto de ser referido como cavaleiro quase um ano antes de ter recebido o adubamento. Ora, esta notícia tem duas interpretações possíveis. Em primeiro lugar, e uma vez que todos os livros da Chancelaria de D. João I foram alvo de reformulação na Leitura Nova, organizada por Gomes Eanes de Zurara em meados do século XV,

\footnotetext{
${ }^{27}$ Estoria de Dom Nuno Alvrez Pereyra, Adelino de Almeida Calado (ed.), Coimbra, Universidade de Coimbra, 1991, cap. XXXVII, pág. 92.

${ }^{28}$ Gomes Eanes de Zurara, Crónica do Conde D. Duarte de Meneses, Larry King (ed.), Lisboa, Universidade Nova de Lisboa, 1997, cap. R, pág. 129 = de agora em diante CCDDM.

${ }^{29}$ Fernão Lopes, Crónica de D. João I, M. Lopes de Almeida e A. de Magalhães Bastos (eds.), Porto, Civilização, 1990/91, vol. II, cap. XXXVIII, págs. 95-97 = de agora em diante CDJI.

${ }^{30}$ Chancelarias Portuguesas. D. João I, João Alves Dias (ed.), Lisboa, Centro de Estudos Históricos, 2004-2006, vol. I, t. I (1384-1385), docs. 36 e 108. O mesmo acontece com outros indivíduos, como Estêvão Vasques Filipe (Chancelarias Portuguesas. D. João I, vol. I, t. I (1385), doc. 336) e Pêro Lourenço de Távora (Chancelarias Portuguesas. D. João I, vol. I, t. II, doc. 877).

${ }^{31}$ Vasco Lobeira, em Chancelarias Portuguesas. D. João I, vol. II, t. II (1387-1402), doc. 922.

32 João Vasques de Almada (Chancelarias Portuguesas. D. João I, vol. I, t. III (1384-1388), doc. 1224) e de Rodrigo Afonso de Aragão (Chancelarias Portuguesas. D. João I, vol. II, t. II, doc. 880 e vol. III, t. I (1385-1410), doc. 34), sendo que neste último documento é referido como "cavaleiro criado do rei".

${ }^{33}$ CDJI, vol. II, LVIII, pág. 154
} 
é hipótese que os escrivães se tenham equivocado e tenham colocado cavaleiro no diploma de 1384, ignorando que nessa data ainda não o era. Todavia, o facto de Antão Vasques aparecer num documento de 28 de Agosto de 1385 como «cavaleiro vassalo do rei», recebendo a alcaidaria do castelo de Lisboa, levanta uma hipótese para a qual, de resto, tendo a inclinar-me: a de que a investidura pela mão do monarca pudesse não apenas materializar a indubitável progressão social, que para alguns de facto significou, mas também a entrada na vassalidade direta do rei. Esta circunstância alerta para a necessidade de analisar a relação entre quem dá e quem recebe a cavalaria, aspeto que será explorado na segunda parte do presente estudo. Antes disso, e talvez elucidados pelo exemplo de Antão Vasques, importa analisar a dimensão honorífica do adubamento.

\section{b) A progressão para o estado cavaleiresco}

Em Portugal, é visível um processo de elitização ${ }^{35}$ da cavalaria sobretudo a partir do século XIII. Não ignorando a relevância do lado funcional desta 'instituição' político-social, acentua-se contudo uma vertente honorífica, impulsionadora da sua conversão no código que caracterizou a aristocracia e, até, a própria realeza. Neste sentido, a cerimónia de adubamento começou a socorrerse de uma renovada liturgia. Se os símbolos que ela utilizou eram, em tempos mais recuados, dirigidos quase em exclusivo para os monarcas, vamos ver que, progressivamente, o cerimonial se alargou: englobava por um lado aqueles que assumiam o estatuto de cavaleiro no ordenamento da sociedade e, por outro, os que apesar de ocuparem uma posição mais relevante viam no código cavaleiresco um ideário de vida.

Mas caso se pretenda analisar o sentido destas investiduras a partir das suas primeiras manifestações, há que voltar a fazer referência ao intenso debate internacional acerca das origens e desenvolvimento da cavalaria, num quadro temporal que se estende, grosso modo, entre a ascensão do Império Carolíngio e a estruturação da sociedade feudo-vassálica dos séculos XI-XII ${ }^{36}$. A verdade é que também em Portugal é muito difícil detetar o momento em que surgem efetivamente adubamentos cavaleirescos. E, se no caso das regiões alémPirenéus a discussão se constrói em torno de um amplo conjunto de fontes, desde cartulários e textos monásticos e diocesanos à imensa literatura épica em língua

\footnotetext{
${ }_{34}$ Resenha biográfica deste cavaleiro em Miguel Gomes Martins, Guerreiros Medievais Portugueses, Lisboa, Esfera dos Livros, 2013, págs. 293-317.

${ }^{35}$ Conceito proposto por Karl Ferdinand Werner em Naissance de la Noblesse, Paris, Fayard, 2010, pág. 664.

${ }^{36}$ Remeto novamente para a nota 13 , onde faço referência à obra de Dominique Barthélemy.
} 
vulgar $^{37}$, o cenário em Portugal é muito distinto. Relativamente às cronologias mais recuadas, e colocando o problema de outra forma, dir-se-ia que, se noutros espaços europeus o cerne do debate reside sobretudo na interpretação de uma quantidade significativa de referências ${ }^{38}$, em Portugal, apesar de a questão também se colocar ao nível da interpretação, o problema maior é, contudo, o parco material fornecido pelas fontes.

Apesar de tudo, uma primeira observação global acerca das notícias examinadas permite detetar a influência da dimensão germânica do ritual, isto é, a valorização do sentido promocional. Num primeiro momento, a entrega de armas aos reis assinalaria a sua ascensão à idade adulta mas também a receção do poder de mando ${ }^{39}$ : tomar a espada do altar materializava a concessão do poder de fazer a guerra e de aplicar a justiça, direitos e deveres inerentes à figura do monarca ${ }^{40}$.

Na Hispânia, tudo parece apontar para que se tenha dado uma confluência entre as práticas ibéricas, influenciadas pelo passado visigótico, e aquelas que entretanto foram trazidas na sequência da crescente ligação ao mundo transpirenaico. Neste sentido, o reinado de Afonso VI de Leão e Castela é um momento de capital importância, em especial pelo casamento das suas filhas Urraca e Teresa com dois nobres borgonheses: Raimundo e Henrique ${ }^{41}$. O filho do primeiro casal, o Imperador Afonso VII, teria sido investido duas vezes. Em 1111, pela mão do arcebispo Diego Gelmirez, o então pequeno Afonso Raimundes foi ungido e recebeu a espada, símbolo da sua realeza e manifesto que, na luta entre os poderes galegos e Afonso I de Aragão, elevava o neto do conquistador de Toledo à soberania. Em 1124 deu-se uma segunda investidura, agora com um sentido de promoção efetiva ao poder mas também, segundo Bonifacio Palacios, com evidentes conotações cavaleirescas ${ }^{42}$. Numa cronologia próxima à do Imperador da Hispânia ter-se-á dado o adubamento de Afonso Henriques. O pequeno relato

\footnotetext{
${ }^{37}$ A já citada obra L'Essor de la Chevalerie, da autoria de Jean FLoRI, continua a ser uma síntese que permite constatar essa dimensão.

${ }^{38}$ Volto a mencionar o debate em torno do sentido de adouber, a que fiz referência na nota 13.

39 Jean FloRI, L'Essor de la Chevalerie..., págs. 113-115.

${ }^{40}$ É preciso ainda considerar a complexidade do cerimonial de cariz feudo-vassálico que entretanto se desenvolve na Península Ibérica. Para este aspeto ver Hilda Grassotti, Las Instituciones FeudoVasalláticas en León y Castilla, 2 vols., Spoleto, Centro Italiano di Studi Sull'alto Medioevo, 1969. Apesar de tudo, e como salienta Dominique BARTHÉLEMY, é necessário não colocar ao mesmo nível os aspetos vassálicos e cavaleirescos (La Chevalerie, pág. 224).

${ }^{41} \mathrm{Na}$ lógica dos contactos com as regiões onde floresceu a ideologia cavaleiresca, faça-se ainda referência ao casamento de Elvira, irmã de D. Teresa, com o conde Raimundo IV de Toulouse, um dos líderes da Primeira Cruzada.

${ }^{42}$ Bonifacio Palacios Martín, "Investidura de Armas de los Reyes Españoles...”, págs. 159-163.
} 
descreve que o filho da rainha Teresa e do conde Henrique, com 14 anos, se teria armado a si próprio, levantando as armas do altar ${ }^{43}$.

A notícia, escrita por um Cónego Regrante de Santa Cruz de Coimbra à volta de 1185 , tenta demonstrar a capacidade de Afonso Henriques se investir à maneira dos reis hispânicos. $\mathrm{O}$ ato parece ter um desígnio eminentemente promocional, coincidindo com o projeto político de $\mathrm{D}$. Teresa ${ }^{44}$. Além disso, na época em que o texto foi escrito, há também uma tentativa de legitimar de forma incontestável a independência portuguesa, atribuindo ao jovem Afonso Henriques a aptidão para se armar a si próprio, sem precisar de receber os símbolos de poder das mãos de outro rei ou de um prelado, tal como havia sucedido com o seu primo Afonso VII. Para Bonifacio Palacios, esta é uma ‘invenção' do relato, e que tem em conta os hábitos do final do século XII, e não a praxis do início dessa centúria. Não por acaso, em 1170, é o próprio Afonso Henriques quem investe o seu filho e herdeiro D. Sancho $\mathrm{I}^{45}$. Seja como for, e interpretando globalmente estas cerimónias, a realidade é que elas parecem ir no mesmo sentido: promover o indivíduo à idade adulta, capacitá-lo para o exercício de funções militares, e atestar a sua aptidão para receber o poder de mando ${ }^{46}$.

É por isso visível em que medida, ao longo do século XII, se fez sentir o peso das antigas heranças germânicas. Ao mesmo tempo, e progressivamente, vai-se constatando a entrada na Hispânia de elementos característicos do mundo

\footnotetext{
43 "Aera 1163 infans inclytus domnus Alfonsus comitis Henrici et regine D. Tarasie filius, domini Alfonsi nepos, habens aetatis annos fere quatordecim apud sedem zamorensem ab altari sancti Salvatoris ipse sibi manu propria sumpsit militaria arma et ibidem in altari indutus est et accinctus militaribus armis sicut moris est regibus facere. Induit vero se loricam sicut gygas, qui magnus erat corpore, et succinxit se arma bellica sua in praeliis similis factos est leoni in operibus suis, et sicut catulus leonis rugiens in venatione", em Bonifacio Palacios Martín, "Investidura de Armas de los Reyes Españoles ...”, pág. 190, nota 127.

${ }^{44}$ José Mattoso, D. Afonso Henriques, Lisboa, Temas e Debates, 2011, págs. 54-56; Mário BARroca e Luís Carlos Amaral, Teresa: a condessa-rainha, Lisboa, Círculo de Leitores, 2012, págs. 225-226. 45 "Era $\mathrm{M}^{\mathrm{a}} \mathrm{CC}^{\mathrm{a}} \mathrm{VIII}$ mense agusto in die dormicionis sancte Marie armatus est rex sancius a patre suo apud Colimbriam", em "Chronicon Conimbricense", em Portugaliae Monumenta Historica, Scriptores, vol. I, Lisboa, 1856, pág. 3.

${ }^{46}$ Maria João Branco defende que, depois do desastre de Badajoz, em 1169, e da incapacidade de D. Afonso Henriques em continuar nos campos de batalha, pretende-se desde logo indicar ao reino qual a linha sucessória. Todavia, e pelo menos nesta data em concreto, o facto de o monarca entregar as armas ao seu filho e não permitir que ele se armasse a si próprio era um sinal de que o Conquistador não admitia abrir mão do governo do reino. Ainda de acordo com Maria João Branco, o adubamento teria igualmente a intenção de marcar a entrada do herdeiro na idade adulta, atestando a sua capacidade de liderar operações militares. No caso, o propósito era entregar ao Infante o comando de um novo ataque a Badajoz. O rei, fisicamente impossibilitado, far-se-ia representar pelo seu herdeiro. Em Maria João Branco, D. Sancho I, Lisboa, Temas e Debates, 2010, págs. 74-79.
} 
cavaleiresco. Por exemplo, é em 1188 que surge a primeira referência à colée, ou seja, à bofetada aplicada ao novo cavaleiro no momento do adubamento ${ }^{47}$.

Contudo, estas notícias remetem-nos apenas para o entorno régio. Em Portugal, tanto quanto pude apurar, não existe nesta cronologia nada de semelhante que se reporte aos círculos aristocráticos. Creio que essa ausência se pode explicar, pelo menos no século XII, por um certo afastamento da aristocracia relativamente à ideologia cavaleiresca. Seja como for, os parcos vestígios relativos a esta época não permitem que se afirme de forma contundente que teria existido qualquer coisa como uma rejeição. É um facto que guerrear a cavalo não era apenas apanágio da nobreza. Bem pelo contrário, a cavalaria vilã desempenhou um papel essencial na Reconquista. Apesar de partilharem funções, parece-me inverosímil que a aristocracia aderisse entusiasticamente a uma cartilha passível de esbater as diferenças face a outro grupo ${ }^{48}$; aliás, em muitos dos casos, os cavaleiros dos concelhos eram até oriundos de regiões cujos contornos estruturais eram assaz divergentes do mundo senhorial predominante a norte do rio Vouga. ${ }^{49}$. Convém ainda salientar que as fontes literárias dos séculos XIII e XIV, à exceção do romance arturiano e, em algumas passagens, dos Livros de Linhagens, não fizeram propriamente uma apologia entusiástica desta conceção da cavalaria. Para isso teríamos de esperar sobretudo pela pena dos cronistas do século XV.

Todavia, os três Livros de Linhagens, compostos entre cerca de 1280 e 1340, e com algumas refundições até ao fim do século XIV ${ }^{50}$, contêm algumas notícias de adubamentos. Estas fontes são simultaneamente, e também devido às referidas notícias, os primeiros testemunhos de monta para analisar com maior profundidade a relação entre a aristocracia e a cavalaria, na sua dupla aceção de categoria social e código de vida. De facto, no tempo em que estas obras são completadas, a cavalaria é indiscutivelmente uma categoria da fidalguia, construindo paralelamente o seu espaço enquanto ideologia característica do estamento privilegiado. Julgo por isso que as cerimónias mencionadas se enquadram fundamentalmente na materialização do cursus honorum cavaleiresco. A expressão utilizada é sempre «fazer cavaleiro»: ou se diz que determinado indivíduo fez alguns cavaleiros, ou se escreve que $x$ fez cavaleiro $y$. Todos estes aspetos merecem ser analisados.

\footnotetext{
47 Bonifacio Palacios Martín, "Investidura de Armas de los Reyes Españoles...”, pág. 187. Aliás, numa cronologia não muito distante relativamente ao cenário transpirenaico, uma vez que, segundo Dominique BARTHÉLEMY, a primeira referência documental que por aí se encontra à colée data de meados do século XII (La Chevalerie, pág. 226).

48 José Mattoso, "Cavalaria” ... (1), págs. 152-154. Como afirma Jesús Rodríguez Velasco, "No quiere decir que los ricos hombres y los otros hombres honrados no sean caballeros, solamente que no es la caballería lo que los caracteriza“, em "De oficio a estado. La caballería...", pág. 60.

49 José Mattoso, Identificação de Um País..., vol. I, págs. 81-100 e 299-320.

${ }^{50}$ José Mattoso, “A transmissão textual dos Livros de Linhagens”, em Naquele Tempo: Ensaios de História Medieval, Lisboa, Círculo de Leitores/Temas e Debates, 2011, págs. 267-280.
} 
Em primeiro lugar, «fazer cavaleiros» é uma expressão aplicada aparentemente sem critério nas fontes portuguesas, o que pode dar azo a equívocos se não se interpretar a fonte com alguma precaução. Como tive oportunidade de demonstrar, eram utilizadas as mesmas palavras quando se promovia um vilão à nobreza. Portanto, quando se diz que se fez um determinado homem cavaleiro, tanto podemos estar a falar de um nobre, como de um vilão. Contudo, o verbo fazer implica neste contexto a ideia de transformação, como se antes disso aquele sujeito não estivesse em posse de tal estatuto ${ }^{51}$. Há indubitavelmente um sentido de progressão que denota a existência de uma carreira; e, em meu entender, de uma conceção honorífica que se vinha impondo. De todas as notícias de adubamento recolhidas nas várias tipologias de fontes, não discerni a existência de critérios específicos para a utilização de «fazer» ou «armar cavaleiros»: ambas se aplicam aos vários tipos de investiduras. No que respeita às que constam nos Livros de Linhagens, é desde logo evidente que, em comparação com o número de nobres mencionados, a quantidade de notícias de adubamentos é muito reduzida. Já se viu que mesmo nos casos aparentemente mais explícitos era frequente que não sobrevivesse qualquer vestígio do ato. Ainda assim, uma discrepância tão grande suscita interrogações: todos os nobres eram armados cavaleiros? Quantos o eram de facto? As características das fontes portuguesas não permitem responder com exatidão às perguntas formuladas, mas é possível que nem todos passassem pelo rito.

Importa agora analisar os testemunhos propriamente ditos, começando pelo primeiro género: o de um nobre que se diz ter feito determinado número de cavaleiros. É o caso de Fernão Gil de Soverosa, «o que fege trinta e sete

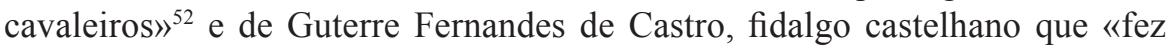
seiscentos cavaleiros per sa mão» ${ }^{53}$. Estas referências podem apontar para homens que, pelo seu prestígio, teriam atraído um número significativo de jovens que desejavam receber a cavalaria pela sua mão. Pode indiciar igualmente a formação de uma mesnada senhorial de grandes dimensões ${ }^{54}$. Nesse caso, o rito assinalaria

\footnotetext{
${ }^{51}$ Retomando uma frase de Jesús Rodríguez-Velasco acerca da investidura: "Sin embargo, todas esas referencias exponen com claridad algún tipo de cerimonial de paso, un momento performativo en el que un acto de habla da lugar a una transformación del sujeto político: alguien que no lo era, passa a ser considerado caballero y com ello adquiere toda una serie de privilégios, una consideración especial, algún tipo de distinción de carácter social y ciertas exenciones fiscales de diversa categoría", em Ciudadanía, Soberanía Monárquica y Caballería: Poética del Orden de Caballería, Madrid, Akal, 2009, pág. 32.

${ }^{52} L D, 14 \mathrm{H} 9$, pág. 172.

${ }^{53} L L, 11 \mathrm{~B} 6$, vol. I, pág. 164.

${ }^{54}$ Uma vez que esses cavaleiros podiam ser homens de poucas posses, integrando-se por isso na vassalagem de alguém mais poderoso. Este caso é tipificado no exemplo de João de Aboim, sobre quem se diz ter sido "ricomem, e houve muitos cavaleiros por vassalos" $-L L, 36 \mathrm{X} 9$, vol. I, pág. 415.
} 
a criação ou a consolidação de um laço feudal, entre senhor e vassalo. Penso que essa imagem é ainda mais visível no outro tipo de menções, quando se alude a um nobre que fez cavaleiro determinado indivíduo. Os Livros de Linhagens contam-nos que Gonçalo Gomes de Briteiros foi investido por Gonçalo Mendes de Sousa ${ }^{55}$; que Fernão Garcia de Bragança armou Nuno Martins de Chacim ${ }^{56}$; que Gonçalo Anes da Nóvoa armou Soeiro Pais de Valadares ${ }^{57}$. Pelo menos nas duas primeiras situações é possível detetar uma relação de vassalidade entre quem recebe e quem dá a honra ${ }^{58}$, pelo que parece fazer sentido admitir que esse fosse o corolário de uma educação recebida em casa do senhor. Podiam portanto ser adubamentos que cumpriam uma função ideológica no sentido em que materializavam a progressão na carreira cavaleiresca. Existia, porém, um intuito prático, não necessariamente desligado do foco ideológico e que, à imagem do que era feito com os reis, pretendia marcar a entrada na idade adulta ${ }^{59}$. De acordo com Leontina Ventura, Nuno Martins de Chacim foi investido por volta de 1237 $38^{60}$. Se considerarmos que o Rico-homem da corte de D. Dinis e herdeiro dos Braganções só viria a morrer em 1284, há uma forte hipótese de que fosse bastante jovem na altura do seu adubamento.

Também não será coincidência o facto de todos os personagens citados terem vivido no século XIII, tempo em que a difusão do ideário cavaleiresco se acelerou. Além do mais, e no que concerne aos círculos aristocráticos, esta era uma época em que as fronteiras políticas se esbatiam ante as ligações familiares. Daí a tão acentuada mobilidade entre os diferentes reinos peninsulares, com estadias breves ou demoradas motivadas por razões eminentemente políticas ${ }^{61}$. Não obstante, seriam temporadas em que os que partiam poderiam conhecer outras realidades. Para começar, não eram raros os contactos com as áreas mais longínquas da Hispânia, como os reinos de Navarra e de Aragão. É sabido que alguns nobres portugueses tiveram oportunidade de estar nessas regiões, as quais, até pela

\footnotetext{
55 LD, 6AU7, pág. 118

${ }^{56} L D, 12 \mathrm{D} 6$, pág. 163; $L L, 38 \mathrm{~B} 6$, vol. I, pág. 441.

${ }^{57}$ LD, 1904, pág. 199; LL, 13C3, pág. 179.

58 José Augusto de Sottomayor-PiZArro, Linhagens Medievais Portuguesas (1279-1325): Genealogias e Estratégias, dissertação de doutoramento apresentada à Universidade do Porto, Porto, 1997, vol. II, pág. 751 e vol. I, págs. 232-245. Esta tese foi publicada (Linhagens Medievais Portuguesas, 3 vols, Porto, Universidade Moderna, 1999) mas utilizo a versão académica por facilidade de pesquisa.

${ }^{59}$ O que acentua a dimensão feudal do ato (Dominique BARTHÉLEMY, La Chevalerie..., págs. 215-220).

${ }^{60}$ Leontina Ventura, A Nobreza de Corte de D. Afonso III, dissertação de doutoramento apresentada à Universidade de Coimbra, Coimbra, 1992, vol. II, pág. 626.

${ }^{61}$ José Augusto de Sottomayor-Pizarro, "De e para Portugal: a circulação de nobres na Hispânia Medieval (séculos XII a XV)”, Anuario de Estudios Medievales, vol. 40, n. 2 (2010), págs. 889924; João Paulo Martins FerReIRA, Entre a Consanguinidade e a Naturalidade: a movimentação da Nobreza Portuguesa entre os reinos de Portugal e Leão (1157-1230), dissertação de mestrado em História Medieval apresentada à Universidade do Porto, Porto, 2009.
} 
maior proximidade geográfica, conviviam mais regularmente com as influências culturais transpirenaicas. De entre estes casos, é impossível ignorar a figura de João Soares de Paiva, um dos primeiros trovadores portugueses ${ }^{62}$, ou ainda o Infante Pedro Sanches, senhor de Maiorca ${ }^{63}$. Ainda assim, a fidalguia portuguesa passou em maior número para as terras de Leão e de Castela, onde poderá ter tido a oportunidade de presenciar o cerimonial que aí se praticava. Apesar de não termos qualquer menção do género nas fontes portuguesas, é sabido que desde o século XII as investiduras cavaleirescas dos reis leoneses eram oportunidades para armar outros cavaleiros ${ }^{64}$ - fidalgos, certamente. Por todas estas razões, não é descabido admitir a propagação de novos rituais, posteriormente copiados em Portugal - num tempo em que, cada vez mais, a aristocracia lusa tendia a ver na sua congénere do outro lado da raia o modelo exemplar ${ }^{65}$.

Para o final da Idade Média explodem os testemunhos e as descrições de investiduras. Desde logo na cronística, com as obras de Fernão Lopes, de Gomes Eanes de Zurara e de Rui de Pina. Todavia, também os homens que viveram nesse tempo procuraram deixar um testemunho de que foram armados cavaleiros, nomeadamente nos seus epitáfios tumulares ${ }^{66}$. Estes casos apontam claramente para a crescente importância do lado honorífico. Daí que encontremos registos de adubamentos de indivíduos de origem 'popular', de pequenos e de grandes nobres, e de reis. Era o tempo em que a cavalaria se tornara definitivamente na imagem identificativa dos grupos privilegiados. Como diria o Infante D. João, algures por 1430, «os que em nosso estado vyuem não podem ser quanto ao deste mundo ditos bons se honrra de Caualaria non alcanção» ${ }^{67}$.

Tendo em conta que já se aludiu com algum detalhe às cerimónias que permitiam a ascensão de 'populares' à nobreza, parece-me agora mais pertinente focar a atenção nos que se submetiam ao ritual como forma de, segundo o Infante D. João, serem honrados. Uma vez que o volume de informação relativo ao

\footnotetext{
${ }^{62}$ José Carlos Miranda, Aurs Mesclatz ab Argen: sobre a primeira geração de trovadores galego -portugueses, Porto, Edições Guarecer, 2004, págs. 15-77.

${ }_{63}$ João Paulo Martins Ferreira, Entre a Consanguinidade e a Naturalidade..., pág. 208. Pedro Sanches viveu, de resto, no mesmo ambiente que Raimundo Llull, um dos maiores teóricos da cavalaria.

${ }^{64}$ Bonifacio Palacios Martín, "Investidura de Armas de los Reyes Españoles...", pág. 161.

${ }^{65}$ Aqui refiro apenas as trocas no âmbito peninsular. Cite-se ainda, e para o século XIII, a figura do Infante D. Fernando, filho de D. Sancho I e conde da Flandres. José Carlos Miranda destaca a importância deste personagem para a difusão do romance arturiano em Portugal ("Como o Rei Artur e os Cavaleiros da sua Corte demandaram o Reino de Portugal", Revista Colóquio Letras, 142 (1996), págs. 98-99).

${ }^{66}$ Consulte-se o levantamento feito por Luís Filipe Pontes em Do mundo da corte ao mundo da memória - subsídios para o estudo da mentalidade cavaleiresca da nobreza portuguesa, 1400-1521, dissertação de mestrado apresentada à Universidade Nova de Lisboa, Lisboa, 2008.

${ }^{67}$ Livro dos Conselhos de el-rei D. Duarte..., pág. 47.
} 
final da Idade Média é deveras abundante, apenas aflorarei alguns exemplos que considero paradigmáticos.

Começo por me reportar ao adubamento de João Afonso Telo, no dia em que também foi feito conde de Barcelos. Fernão Lopes descreve com detalhe uma cerimónia de grande pompa ${ }^{68}$. Tanto neste caso como nos outros que adiante citarei, apenas me referirei à questão do significado do evento, deixando a análise do ritual propriamente dito para a segunda parte deste estudo. Para já, importa ter presente a intenção de investir um dos nobres mais proeminentes do reino ${ }^{69}$. Neste caso em concreto foi uma festa de corte, o que é sintomático de como, a partir do século XIV, a cavalaria se convertera numa forma de relacionamento entre o rei e a fidalguia. Ainda assim, e contrariamente ao que acontecia em séculos anteriores, João Afonso Telo não recebia armas para ser consagrado numa qualquer função. Juridicamente, o adubamento nada tem a ver com a receção do condado de Barcelos. É, apenas e só, um ato prestigiante, destinado a ilustrar a sua nobreza.

Claro que alguns se podiam tornar cavaleiros sem nunca pisar um campo de batalha; noutros casos, todavia, não terá sido assim, o que em certa medida atenua a visão de que só nos séculos XII e XIII é que os cavaleiros viviam pelas armas ${ }^{70}$. No final da Idade Média, o exemplo dos Meneses é talvez o que melhor ilustra estes aspetos. Depois do seu importante papel como capitão de Ceuta, D. Pedro de Meneses recuperou definitivamente o prestígio da linhagem ${ }^{71}$. Além de se tornar no primeiro titular da nova dinastia, depois dos Infantes e de Nuno Álvares Pereira, e por isso gozar de um capital de prestígio simbólico e material quase sem par no reino, D. Pedro não abandonou o seu perfil guerreiro. Não abdicou, portanto, de permanecer em Ceuta até ao final da sua vida. Apesar de legar o condado de Vila Real a D. Beatriz, procurou manter a vocação cavaleiresca dos Meneses por

\footnotetext{
${ }^{68}$ Fernão Lopes, Crónica de D. Pedro, Giuliano Macchi (ed.), Lisboa, Imprensa Nacional-Casa da Moeda, 2007, cap. XIV, págs. 60-61.

${ }^{69}$ Rita Costa Gomes, A Corte dos Reis de Portugal no final da Idade Média, Lisboa, Difel, 1995, págs. 64-72.

${ }^{70}$ Creio ser importante apresentar um exemplo de como em Castela, pela mesma época, o cenário seria semelhante. Uma carta de armas de Henrique IV em favor de Miguel Lucas de Iranzo conta que, pelos contínuos serviços deste, o monarca decidira enobrecêde -lo. Já depois de o ter favorecido, Henrique IV terá ficado sensibilizado com o ardor guerreiro demonstrado pelo seu vassalo nas guerras em Granada, pelo que "por mi mano y com mi espada desnuda, sacada fuera de la vaina os armé Caballero de espuelas doradas, com aquella solemnidad que demanda y requiere la caballería" (documento transcrito em Maria Concepción Quintanilla Raso, Nobleza y Caballería en la Edad Media, Madrid, Arcos Libros, 1996, págs. 71-72). Por esta situação se percebe a dimensão honorífica da cavalaria, neste sentido independente do estatuto de nobreza, mas que pode sem dúvida ilustrá-la e reforçá-la. Por outro lado, demonstra como, nesta cronologia, muitos continuaram a merecer a honra pela sua valia nos campos de batalha.

${ }^{71}$ Para estes aspetos ver Nuno Silva CAmpos, D. Pedro de Meneses e a construção da Casa de Vila Real (1415-1437), Lisboa, Colibri/CIDEHUS, Évora, 2005.
} 
intermédio do seu filho ilegítimo, D. Duarte. Aquando do seu adubamento, não terá deixado de lhe vaticinar um futuro risonho: pelo seu valor, D. Duarte iria certamente «ganhar homrra e nome» ${ }^{72}$.

E que melhor testemunho da alteração do paradigma da cavalaria nesta época do que o relato de adubamento do rei D. Fernando? Segundo Fernão Lopes, o monarca foi interpelado pelo conde de Cambridge com o argumento de que, apesar de ser rei, não podia fazer cavaleiros sem o próprio ter passado pela investidura. D. Fernando foi armado cavaleiro pelo conde Edmundo nas margens do Caia, em Agosto de $1382^{73}$. Como é evidente, o rei não tinha necessidade de se submeter a este cerimonial para assumir as funções régias. Nada, portanto, do caráter promocional que a entrega das armas significava em séculos precedentes. Apesar de partilharem o mesmo estatuto, o significado das investiduras de D. Afonso Henriques ou de D. Sancho I, de caráter eminentemente promocional, pouco tem a ver com a de D. Fernando. Aliás, mesmo que esta não tenha de facto acontecido, temos pelo menos um testemunho de como é que a corte régia portuguesa do início de Quatrocentos encarava a cerimónia, e em especial a ligação entre a realeza e a instituição cavaleiresca. Com efeito, tanto o hipotético caráter verídico como o ficcional do episódio acentuam um cunho puramente honorífico, de que não se pode desligar algum sentido de adesão a uma moda própria das cortes mais avançadas da época, como era a inglesa. Poderá ser também um indício de que os monarcas portugueses não tinham o hábito de ser armados cavaleiros, pelo menos à imagem do que, no século XV, e sob a ótica de Fernão Lopes, significaria esta cerimónia.

Apesar de tudo, creio que o cerne desta questão pode residir numa diferença de paradigmas: entre aquilo que porventura seria a tradição ibérica, ainda que progressivamente influenciada por elementos exógenos, e o modelo inglês, impulsionado a novos desenvolvimentos em particular no reinado de Eduardo III $^{74}$. Não se pode deixar de observar em que medida esta ideia era passível de discussão. A Segunda Partida estabelecia claramente a necessidade de um rei ser armado cavaleiro, salientando ainda que um cavaleiro não podia ser feito por mão de quem não o fosse ${ }^{75}$. $\mathrm{O}$ texto defendia que os monarcas adotassem a simbologia cavaleiresca, tentando, por essa via, construir novas formas de relacionamento com a própria nobreza. No entanto, esta ideia não era acolhida

\footnotetext{
72 Gomes Eanes de Zurara, Crónica do Conde D. Pedro de Meneses, Maria Teresa Brocado (ed.), Lisboa, Gulbenkian, 1997, $2^{\text {a }}$ parte, cap. XXII, págs. 634-638 = de agora em diante CCDPM.

${ }^{73}$ Fernão Lopes, Crónica de D. Fernando, Giuliano Macchi (ed.), Lisboa, Imprensa Nacional da Casa da Moeda, 2004, cap. CLIII, págs. 531-532= de agora em diante CDF.

${ }^{74}$ Nigel SAul, For Honour and Fame: Chivalry in England, 1066-1500, London, Pimlico, 2012, págs. 93-113. Algumas décadas antes, o Príncipe Negro também teria armado cavaleiro o rei Pedro I de Castela ( $C D F$, cap. CVI, págs. 25-26).

${ }^{75}$ PII, título XXI, pág. 183.
} 
com unanimidade. Don Juan Manuel reclamava ter o poder de armar cavaleiros mesmo que ele não o fosse, argumentando que não tinha esse estatuto porque, atendendo à sua condição, só seria digno passar pela cerimónia se ela fosse feita à maneira dos reis ${ }^{76}$. Resumindo, é notório como já na segunda metade do século XIII e na centúria seguinte este tópico era debatido. O que não deixa de parecer estranho, à luz tanto das perspetivas enunciadas por Fernão Lopes como do comportamento dos monarcas portugueses, é o que a este respeito se prescreve nas Ordenações Afonsinas ${ }^{77}$. Apesar de o texto ser praticamente uma cópia do título XXI da Segunda Partida, divergia da compilação legislativa do rei Sábio exatamente neste ponto: os monarcas, por usufruírem da sua real dignidade, superior a todas, têm o poder de fazer novos cavaleiros mesmo «sem recebendo outra ordem de cavalaria», devendo-se essa prerrogativa ao facto de, por serem reis, logo incluírem na sua condição a «hordem da Cavallaria». A partir do momento em que o soberano é investido na realeza, «logo he feito Cavalleiro».

Apesar das interpretações poderem suscitar dúvidas, creio que se deteta um sentido transversal: a intenção de associar cavalaria e realeza. E, mais do que ficar refém do sentido estritamente legal destes excertos, julgo que é mais útil procurar ter alguma sensibilidade para interpretar a sua intenção global, tentando simultaneamente compreender o papel e o significado que a cavalaria foi assumindo em cada um destes períodos.

Por isso, depois de conquistar Arzila, conta Rui de Pina que D. Afonso V terá chamado o então Infante $\mathrm{D}$. João à mesquita onde jaziam os cadáveres dos condes de Monsanto e de Marialva. Na ressaca da conquista da cidade, e talvez ainda num estado de emoção e adrenalina próprios do sucesso desta enorme operação, o monarca armou cavaleiro o futuro D. João $\mathrm{II}^{78}$. Pouco se vê, portanto, da ideia pretensiosa e exclusivista de que um rei, só por que é rei, reúne em si as virtudes da cavalaria. Na verdade, os exemplos históricos parecem impelir-nos para a ideia de que em Portugal, no Outono da Idade Média, os reis e os seus herdeiros, assim como fidalgos e 'populares', foram frequentemente para o campo de batalha para merecerem a honra de cavalaria, batendo-se, tal como D. João I teria feito em Aljubarrota, «como se fosse huu simpres cavaleiro desejoso de guardar fama» ${ }^{79}$.

Se a cerimónia teve tantos significados ao longo do período em análise, não será também que a sua ritualização foi assumindo elementos e contornos distintos ao longo desse tempo? É esta questão que valerá agora a pena explorar.

\footnotetext{
${ }^{76}$ Don Juan Manuel, Libro de las Armas, em Obras Completas, José Manuel Blecua (ed.), Madrid, Gredos, 1982, págs. 127-134.

77 OA, Título LXIII, págs. 365-366.

${ }^{78}$ Rui de Pina, Chronica do senhor rey D. Affonso V, em Crónicas de Rui de Pina, M. Lopes de Almeida (ed.), Porto, Lello \& Irmãos, 1977, Cap. CLXV, págs. 821-823.

${ }^{79}$ CDJI, vol. II, cap. XLII, págs. 107.
} 


\section{O RITUAL}

Relata Fernão Lopes que, quando D. Pedro I decidiu armar cavaleiro João Afonso Telo, «fez-lhe a moor honrra em sua festa que ataa'quelll tempo fora vista que rrei nehiu fezesse a semelhante pessoa ${ }^{80}$. Mandaram-se fazer cerca de cinco mil círios e tochas, entregues, segundo o cronista, a outros tantos homens vindos dos arrabaldes de Lisboa, e que se colocaram entre o paço do monarca e o mosteiro de S. Domingos. Nesse espaço, o rei e os seus pares dançavam e festejavam. No mosteiro, contudo, estava João Afonso Telo, a «velar suas armas». No dia seguinte, no Rossio, foram armadas grandes tendas, onde havia enorme quantidade de pão, carne e vinho para usufruto de todos. No fim das festas, D. Pedro I procedeu às cerimónias de adubamento de João Afonso Telo e de «outros cavaleiros».

Este episódio reúne muitos dos lugares-comuns associados à cavalaria. É frequente pensar-se que a vigília noturna era um costume tradicional, associado à missão 'sagrada' que o cavaleiro teria no ordenamento da sociedade. O fausto e o aparato das festas aqui retratadas também correspondem à imagem de grandiosidade que geralmente se tem dos cavaleiros. Aqui se dá, aliás, a fusão entre os elementos germânicos - as armas - com a dimensão religiosa - a vigília.

Todos estes elementos estão sintetizados quer em obras tratadísticas, quer nos títulos da Segunda Partida e das Ordenações Afonsinas a que se tem feito referência. É interessante notar que, na globalidade dos textos que aludem à cerimónia, à exceção de pequenas nuances, o ritual sugerido é semelhante. No Livro da Ordem de Cavalaria ${ }^{81}$, Raimundo Llull afirma que para se armar um novo cavaleiro se deve aproveitar uma das festas honradas do ano. Nessa ocasião juntarse-ia muita gente que rezaria pelo escudeiro. Entretanto, o candidato deveria jejuar na véspera da festa, passando a noite na Igreja «em oração e em contemplação», ouvindo «palavras de Deus e da ordem de cavalaria». No dia seguinte canta-se missa solene. No fim, o escudeiro «deve ajoelhar-se perante o altar»; entretanto, «o cavaleiro deve cingir a espada, para significar castidade e justiça. E como significado de caridade deve beijar o escudeiro e dar-lhe uma bofetada [a colée ou pescoçada], para que se lembre do que prometeu e do grande cargo a que fica obrigado, e da grande honra que recebe pela ordem de cavalaria». Depois disso, o novo cavaleiro deve cavalgar e mostrar-se às pessoas, para que todos saibam que agora está investido desse estatuto.

Este é, grosso modo, o protocolo idealizado da cerimónia de adubamento. Outras obras, como o anónimo Ordene de Chevalerie e o Livre de Chevalerie, escrito por Geoffroi de Charny, sublinham ainda a necessidade de o cavaleiro se banhar no dia anterior, lavando-se física e moralmente antes de receber a honra

\footnotetext{
${ }^{80}$ Fernão LoPes, Crónica de D. Pedro..., cap. XIV, págs. 60-61.
} 
de cavalaria ${ }^{82}$. Charny alude também à entrega de esporas douradas. As Partidas estabeleceram ainda a obrigatoriedade de o novo cavaleiro receber a espada na mão direita, jurando que morreria pela lei, pelo senhor e pela terra ${ }^{83}$.

Tal como defendem reputados autores como Maurice Keen e Richard Barber ${ }^{84}$, nestes textos, ainda que teóricos, é percetível em que medida se cruza a influência germânica, de cariz essencialmente secular, com rituais cristianizados, resultantes quer de uma interferência da Igreja, quer de uma expressão de piedade própria destes homens com o objetivo de fundamentar o seu lugar na sociedade ${ }^{85}$.

Dir-se-ia que todos estes documentos têm mais elementos a uni-los do que a separá-los, apesar de cada nuance resultar de um contexto específico. Para o que de momento interessa, a questão mais pertinente é saber qual a tradução efetiva desta teorização para a prática. Para isso há que analisar as descrições fornecidas pela cronística. Considerando as caraterísticas das fontes portuguesas, a primeira constatação é de que o quadro que se traça resulta do material disponível, e, por isso, dar-nos-á uma visão baseada em narrativas cronísticas que refletem com segurança o panorama do final da Idade Média. Para períodos anteriores, como os séculos XII e XIII, é praticamente impossível aproximarmo-nos com coordenadas sólidas de como seriam praticadas as investiduras em Portugal. A não ser que entretanto surja algum testemunho revelador ou revolucionário, restam-nos deduções com base em aproximações àquilo que acontecia noutros pontos do Ocidente Medieval, em especial na Península Ibérica.

Assim sendo, a conclusão imediata a que se chega é que nenhum dos relatos disponíveis é compatível com as observações feitas nos textos legislativos e tratadísticos, o que coloca sérias reservas ao cumprimento integral do cerimonial proposto. Naturalmente que a visão que se pode construir está condicionada pelos testemunhos que nos chegaram do passado. Tal como já referi, nem todas as investiduras mereceram memória. Ainda assim, e vistas as coisas na sua

\footnotetext{
${ }^{81}$ Raimundo Llull, Livro da Ordem de Cavalaria..., cap. IV, págs. 45-48.

${ }^{82}$ Maurice Keen, Chivalry..., págs. 64-65; Geoffroi de Charny, A Knigt's Own Book of Chivalry, Richard W. Kaeuper e Elspeth Kennedy (eds.), Philadelphia, University of Pennsylvania Press, 2005, págs. 91-93. Esta prática daria origem, na Inglaterra do século XV, a uma designação própria: os "knights of the bath", isto é, os cavaleiros que passavam pelo banho como forma de receber essa dignidade. Nesta centúria, tal prática tornara-se num mecanismo de propaganda régia, uma vez que estava associada a importantes festas de corte. Para esta questão ver o já citado estudo de Fionn PILBRow, "The Knigths of the Bath...", págs. 195-218.

${ }^{83}$ PII, título XXI, págs. 185-186.

${ }^{84}$ Maurice Keen, Chivalry..., págs. 64-82; Richard BArber, The Knight and Chivalry..., págs. 30 37.

${ }^{85}$ Richard W. KAEUPER, Chivalry and Violence in Medieval Europe, Nova Iorque, Oxford University Press, 1999, págs. 45-53.

${ }^{86}$ Dominique Barthélemy, La Chevalerie..., págs. 304-305.
} 
globalidade, presumo que, em Portugal, estas prescrições só muito raramente seriam observadas. A grande maioria dos testemunhos que chegou até aos dias de hoje dá conta de um rito muito mais simples do que o há pouco enunciado. Dominique Barthélemy sugere que o adubamento dos séculos XI e XII era um ato «de geometria variável», constituído por elementos facultativos ${ }^{86}$. Como se vê, e pelo menos a julgar pelo caso português, a maleabilidade do ritual, exposto ao contexto particular de cada ato, parece ser a regra.

A súmula das notícias recolhidas permite que se façam algumas observações. É possível perceber a existência de um momento ideal, compreender a importância da relação entre quem dá e quem recebe a cavalaria, e esboçar aquele que seria, em linhas gerais, o ritual praticado. Analisem-se estes aspetos sequencialmente.

\section{a) O momento ideal}

A primeira diferença entre a teoria e a prática é desde logo visível no momento que, na cronística, surge claramente como o ideal para realizar um adubamento. De entre as dezenas de informações recolhidas, é sintomático que todas - à exceção de João Afonso Telo - se reportem direta ou indiretamente a um cenário bélico $^{87}$. A guerra destaca-se enquanto palco ideal, aquele que legitima o novo cavaleiro. Não há referências ao Pentecostes ou a investiduras nas coroações régias. Exemplo das grandes festas do ano, sugeridas por Raimundo Llull, só se encontra para D. Sancho I, que terá sido armado cavaleiro no dia 15 de Agosto. Apesar de tudo, poder-se-á argumentar que tal discrepância de testemunhos se deve fundamentalmente ao critério dos cronistas, muito mais sensíveis a elementos guerreiros; é até plausível admitir que a observação de um fenómeno tão marcante como a guerra possa ter inquinado o panorama.

Contudo, outros dados apontam claramente no sentido de considerar que esta discrepância não se deve apenas ao olhar dos cronistas: era de facto a mentalidade daqueles homens, dos que queriam ascender ao estado cavaleiresco. Dois dos Infantes da Ínclita Geração dão voz a esta perspetiva. Segundo Rui de Pina, o Infante D. Fernando teria feito pressão para avançar sobre Tânger porque, ao contrário dos irmãos mais velhos que foram a Ceuta, «em cuja empresa e perigo merecestes e vos deram [aos Infantes D. Duarte, D. Pedro e D. Henrique] a honrra da Cavallaria que tendes», D. Fernando ainda não fizera «cousa que pareça de Cavaleyro» ${ }^{88}$. Mais

\footnotetext{
${ }^{87}$ Maurice KEEN defendeu que a guerra era uma das ocasiões primordiais para receber a cavalaria (Chivalry..., págs. 79-80). Em França, no final da Idade Média, também os "adoubements militaires" foram os mais frequentes (Philippe Contamine, "Points de vue sur la chevalerie en France à la fin du Moyen Âge”. Francia, 4 (1976), págs. 272-282).

${ }^{88}$ Rui de PInA, Chronica do senhor rey D. Duarte, in Crónicas de Rui de Pina, M. Lopes de Almeida (ed.), Porto, Lello \& Irmãos, 1977, cap. X, págs. 512-514. O itálico consta do próprio texto.
} 
contundente e liberta da manipulação do cronista é a posição do Infante D. João. Pronunciando-se acerca da hipótese de passar novamente ao Norte de África, o quarto filho de D. João I dizia que os homens do seu estado - os defensores, tal como são apelidados nas Ordenações Afonsinas - só são honrados se alcançam a honra de cavalaria, «a qual sem guerra ou peleja se non pode aver e quanto mais desarrezoada e perigosa tanto sua vitoria mais honrada» ${ }^{89}$.

Um outro exemplo demonstra até que ponto se podia exprimir a discordância entre as festas e a guerra. Na Crónica da Tomada de Ceuta, Zurara conta que D. João I andou durante algum tempo a imaginar como podia «mais honradamente dar estado cavaleiroso» aos seus filhos. Pensou em organizar uma festa memorável, para a qual convidaria gentes do reino e de fora dele. Seriam comemorações tão sumptuosas que os que aí fossem teriam «neçesidade de os apregoarem grandemente antre todollos seus amigos». No fim, o rei armaria os seus filhos cavaleiros ${ }^{90}$. Segundo Zurara, os Infantes souberam destes planos e fizeram de tudo para os evitar. Ser investido depois de umas festas era coisa de pequeno valor, própria dos cidadãos e dos filhos de mercadores, até porque «toda a força de sua honra esta na fama da sua despesa». Para a nobreza, o ideal era praticar «grandes feitos de fortaleza com grandes trabalhos e perigos vendo o sangue de jmigos espargido ante seues pees ${ }^{91}$.

O resto da narrativa é relativamente conhecido: os Infantes demoveram o rei e, pelo meio, surgiu a hipótese de Ceuta. Seja como for, mais do que o sentido histórico e factual deste episódio, importa porém a ideia transmitida: a guerra era o melhor dos elementos legitimadores do novo cavaleiro.

Sendo assim, era costume fazerem-se adubamentos antes de batalhas. Na guerra medieval, os enfrentamentos campais de grandes dimensões eram extremamente $\operatorname{raros}^{92}$. Muitos cavaleiros podiam nem sequer ter alguma vez a oportunidade de participar em algum. Por isso, os comandantes tinham de utilizar todos os recursos disponíveis para motivar as tropas, e armar cavaleiros era um deles ${ }^{93}$. Conhecemse vários exemplos deste tipo. No Salado, «elRey de Portugal por sua mão armou alguns cavalleiros ${ }^{94}$. Fernão Lopes fornece-nos uma lista de homens armados

\footnotetext{
${ }^{89}$ Livro dos Conselhos de el-rei D. Duarte..., pág. 47.

90 Gomes Eanes de Zurara, Crónica da Tomada de Ceuta por el rei D. João I, Francisco Maria Esteves Pereira (ed.), Lisboa, Academia das Ciências de Lisboa, 1915, cap. VII, págs. 24-26 = de agora em diante $C T C$.

91 CTC, cap. VIII, págs. 26-27.

92 Miguel Gomes Martins, A Arte da Guerra em Portugal, Coimbra, Imprensa da Universidade de Coimbra, 2014, págs. 450-451; Francisco GARcíA-Fitz, Las Navas de Tolosa, Barcelona, Ariel, 2012, págs. 70-82;

93 Miguel Gomes Martins, A Arte da Guerra em Portugal, págs. 459-460.

94 Rui de Pina, Chronica do senhor rey D. Afonso IV, em Crónicas de Rui de Pina, M. Lopes de Almeida (ed.), Porto, Lello \& Irmãos, 1977, cap. LIX, págs. 446.
} 
cavaleiros antes da batalha de Aljubarrota, a que se juntaram outros não nomeados. Aliás, diz o cronista que o monarca «fazia emtão cavaleiros quuoães quer quue ho seer querião, e falava aos seus muitas rezões desforço ${ }^{95}{ }^{2}$. Em 1437, o Infante D. Henrique também investiu alguns homens no momento em que instalou o arraial sobre Tânger e se preparava para assaltar a cidade $^{96}$.

Mais frequentes eram os adubamentos depois de um recontro. Desses temos muito mais notícias, em especial nas crónicas que se reportam aos feitos portugueses no Norte de África. Organizava-se uma qualquer correria em território inimigo, na qual se matavam alguns mouros, pilhava-se uma aldeia e se traziam cativos, e, no fim, armava-se um novo cavaleiro ${ }^{97}$. Para referir apenas alguns exemplos de entre os muitos disponíveis, citem-se os casos de Antão Gonçalves ${ }^{98}$, uma das figuras centrais da Crónica dos Feitos da Guiné, de Soeiro da $\operatorname{Costa}^{99} \mathrm{e}$ de Pedro Portocarreiro ${ }^{100}$.

Afinal, participar numa qualquer correria em África era o suficiente para se ser armado cavaleiro? Parece-me necessário matizar esta questão. É um facto que os povos em Cortes aludiram frequentemente ao problema ${ }^{101}$. Mas a realidade é que este género de operações - a chamada guerra guerreada ${ }^{102}$ - era o essencial da vida de um cavaleiro. Eduardo III e o seu filho, o Príncipe Negro, ou até Henrique $\mathrm{V}$, foram celebrados pelas inúmeras vezes em que correram o campo inimigo, matando e pilhando ${ }^{103}$. Crécy, Poitiers ou Azincourt eram fenómenos

\footnotetext{
${ }^{95}$ CDJI, vol. II, cap. XXXIII e XXXVIII, págs. 78 e 97. Jean Froissart alude a este episódio (JEAN FroIsSART, Crónicas: duas passagens relativas a Aljubarrota, Ana Sofia Laranjinha e Mário Jorge Barroca (eds.), Fundação Batalha de Aljubarrota, 2008, págs. 35-36). Maurice KeEN também menciona esta situação (Chivalry..., págs. 80-81).

${ }^{96}$ Rui de Pina, Chronica do senhor rey D. Duarte..., cap. XXIV, pág. 542.

${ }^{97}$ Para uma panorâmica acerca do modo de fazer a guerra no Norte de África ver Luís Miguel DuARTE, "África", in José Mattoso (coord.), vol. I, Nova História Militar de Portugal, Manuel Themudo Barata e Nuno Severiano Teixeira (dir.), Lisboa, Círculo de Leitores, 2003, págs. 409-417.

${ }^{98}$ Gomes Eanes de Zurara, Crónica dos feitos notáveis que se passaram na conquista de Guiné por mandado do infante D. Henrique, Torquato de Sousa SOARES (ed.), vol. I, Lisboa, Academia Portuguesa da História, 1997, cap. XIII, págs. 65-69 = de agora em diante $C F G$.

${ }^{99} C F G$, cap. LV, pág. 210.

${ }^{100} C C D D M$, cap. VI, págs. 62-63.

${ }^{101}$ Contudo, e contrariamente ao que tem sido frisado, Portugal não é caso único. O mesmo aconteceu, por exemplo, em Inglaterra e em França: Philippe Contamine, "Points de vue sur la chevalerie en France...", págs. 262-263.

${ }^{102}$ João Gouveia Monteiro, "De D. Afonso IV (1325) à batalha de Alfarrobeira (1449): os desafios da maturidade", em José Mattoso (coord.), vol. I, Nova História Militar de Portugal, Manuel Themudo Barata e Nuno Severiano Teixeira (dir.), Lisboa, Círculo de Leitores, 2003, págs. 224-226; Miguel Gomes Martins, A Arte da Guerra em Portugal..., págs. 338-397.

${ }^{103}$ Nigel SAuL, For Honour and Fame..., págs. 134-151; Craig TAYLOR, "Henry V, Flower of Chivalry”, em Gwily Dodd (ed.), Henry V: New Interpretations, York, York Medieval Press, 2013, págs. 217-247.
} 
praticamente únicos numa vida. Nas praças portuguesas em África o cenário não seria muito distinto. Com a diferença, talvez fundamental, de que essas cidades estiveram constantemente em guerra, não faltando oportunidades para organizar uma surtida em território inimigo. Quando uma dessas operações era bemsucedida, era frequente armar um novo cavaleiro. As crónicas, apesar de serem descrições grandiloquentes e apologéticas, sugerem até que essa nova investidura partiria quase de uma aclamação por parte dos companheiros de armas, os quais, reconhecendo o valor desse guerreiro, sugeriam que ele devia ser investido naquele momento. Conta Zurara que assim terá acontecido com Antão Gonçalves ${ }^{104} \mathrm{e}$ também com D. Duarte de Meneses ${ }^{105}$.

Naturalmente que as fontes narrativas enaltecem o valor destes personagens, pelo que é admissível que os episódios tenham sido sobrevalorizados. No entanto, importa sublinhar que este é o padrão das investiduras narradas nas crónicas de Zurara. Em alguns casos, é possível que elas tenham sido feitas na sequência de um recontro de razoáveis dimensões; noutros, todavia, seria um enfrentamento mais reduzido, mas que, aos olhos daqueles homens, cumpria o propósito essencial de servir de batismo de fogo ${ }^{106}$.

Apesar de tudo, não era a mesma coisa fazer um adubamento depois de um feito sonante, como a conquista de uma cidade. A julgar pelos testemunhos, essa honra centrou-se principalmente na família real. Depois de assaltar vitoriosamente as muralhas de Tuy, a 25 de Julho de 1396, D. João I apoderou-se da cidade no dia seguinte. Nessa altura, o monarca armou cavaleiro o seu filho natural D. Afonso e mais alguns homens que provaram o seu valor ${ }^{107}$. Em Ceuta a história foi semelhante. No domingo seguinte à tomada da praça, depois de ouvir a primeira missa na recém-consagrada igreja, os Infantes recolheram às suas pousadas para se armarem. De regresso à antiga mesquita, D. Duarte, D. Pedro e D. Henrique foram armados cavaleiros; depois, eles próprios procederam à investidura de homens da sua prole ${ }^{108}$.

\footnotetext{
104 “ $O$ feito assy acabado (...) juntaronse todos assy como forom na peleia e começarom de requerer Antam gonçallvez que fosse cavaleiro" em $C F G$, cap. XIII, págs. 65-69.

105 "E por certo que não com pequeno prazer ouvio o comde as novas da bomdade de seu filho, caa the disseram como se ouvera naquele feito com tamto peso em sua ardideza, nõ desfalleçemdo na fortaleza (...) - Senhor, não nos parece que he rrezão que vosso filho vaa daquy sem algum synal de tamta bomdade quamta oje mostro. - E ally lhe começaram de comtar pelo myudo cada hui o que vira (...) E emtã allevamtou a mão com há espada e feze-o cavaleiro", em CCDPM, cap. XXII, págs. 634-638.

${ }^{106}$ Daí que também existam alguns relatos de homens que iam a Ceuta e pediam expressamente para organizar uma cavalgada para serem armados cavaleiros. Foi assim com um duque alemão, que "requero ao comde que the desse XX ou XXX de cavallo, ca queria hyr fazer dous cavaleiros" e com Sancho de Noronha (CCDPM, cap. LX, págs. 441-442 e 2ª parte, cap. XXXV, págs. 684-694). ${ }^{107}$ CDJI, vol. II, cap. CLXXIII, págs. 380-382.

${ }^{108}$ CTC, cap. LRVI, págs. 253-257.
} 
Apesar de mais indivíduos terem recebido a honra neste dia, o centro das festas repousava nos Infantes. Tratava-se de uma ocasião de propaganda régia, razão pela qual se direcionava o foco essencialmente para os membros afetos à Coroa. Quando os Infantes se dirigiam para a igreja, «ante eles hiam muitas trombetas e charamelas»: música, cor e solenidade destinavam-se a engrandecer os feitos dos líderes do reino.

A historiografia que se dedica a estas temáticas destaca ainda a importância das coroações régias e de outras festas de corte como eventos primordiais para fazer cavaleiros ${ }^{109}$. No entanto, em Portugal, e contrariamente a outras regiões europeias, as festas onde se armaram cavaleiros no período final da Idade Média não se desligaram de um ambiente beligerante. Não consegui encontrar qualquer testemunho que indique que os monarcas lusitanos tenham procedido a investiduras no dia em que foram levantados por reis, ao contrário do que se fez em Castela, tanto no século XIV como na centúria seguinte ${ }^{110}$.

\section{b) A relação entre quem dá e quem recebe a cavalaria}

A relação entre quem dava e quem recebia a cavalaria não era neutra. Em alguns casos, pressupunha a existência ou a criação de laços vassálicos. As Partidas referiam que o homem que cingia a espada ao novo cavaleiro deveria ser o seu senhor natural, um homem honrado ou um bom cavaleiro, e que, ao praticar esse ato e confirmar a outorga da ordem de cavalaria, assumia a figura de «padrinho». Por isso, aquele que era investido devia-lhe obediência ${ }^{111}$. É possível que esse padrinho fosse, na maioria das vezes, o próprio senhor feudal. $\mathrm{Na}$ primeira parte deste estudo aludi aos adubamentos referidos nos Livros de Linhagens e demonstrei como é possível detetar relações de vassalidade entre os personagens referidos. No entanto, no final da Idade Média, esta ligação é ainda

\footnotetext{
${ }^{109}$ Maurice Keen, Chivalry..., pág. 79. Segundo Katie Stevenson, estas cerimónias foram até as preferidas pelos monarcas escoceses (Chivalry and the pratices of Knighthood in Scotland, 14211513..., págs. 41-60). Fionn PILBRow também destaca a importância das festas de corte em Inglaterra, embora, como bem demonstra, estas estejam longe de ter sido as únicas ocasiões para armar cavaleiros ("The Knigths of the Bath: Dubbing to Knighthood in Lancastrian and Yorkist England"..., págs. 195-218). Em França este género de eventos também teve muita relevância (Philippe ContaMINE, "Points de vue sur la chevalerie en France...", págs. 272-282). Para o reino de Aragão ver o estudo de Jorge SÁrz Serrano, Caballeros del rey: nobleza y guerra en el reinado de Alfonso el Magnánimo, Valência, Universitat de València, 2008, págs. 251-258.

${ }^{110}$ Citem-se os casos de Afonso XI e de João II - Bernabé Martínez Ruiz, "La Investidura de Armas en Castilla...", págs. 211-215. Ainda assim, a cerimónia de entronização dos reis portugueses na época medieval parece ter sido significativamente mais simples do que as dos reis castelhanos. Para este assunto ver José Matтoso, "A coroação dos primeiros reis de Portugal", em Naquele Tempo: Ensaios de História Medieval, Lisboa, Círculo de Leitores/Temas e Debates, 2011, págs. 487-510. ${ }^{111}$ IIP, título XXI, págs. 186-187.
} 
mais visível. Em Ceuta, cada um dos Infantes armou cavaleiros homens da sua privança, por vezes até criados em suas casas ${ }^{112}$. Através da cerimónia podiam também solidificar-se eventuais laços de amizade, desenvolvidos depois de uma longa convivência que atravessara a infância e a adolescência. Nesse dia, o Infante D. Pedro armou cavaleiro Álvaro Vaz de Almada. O mesmo que com ele percorreria a Europa e que participaria nas guerras frente ao turco ${ }^{113}$, e que, nas vésperas de Alfarrobeira, jurou morrer caso o seu senhor fosse liquidado - como, aliás, veio a acontecer ${ }^{114}$. Porque não admitir que, no momento do pacto, os dois não se lembrariam daquela manhã em Ceuta, trinta e quatro anos antes?

Noutras situações, apesar de não se desenhar um vínculo feudal, é percetível em que medida era importante para o que recebia a investidura ser armado por um honrado e afamado cavaleiro. Na Demanda do Santo Graal, a abadessa incita Lancelote a que seja ele a investir Galaaz, «ca milhor cavaleiro ca vós nom no pode fazer cavaleiro ${ }^{115}$. De acordo com Rui de Pina, o Infante D. Pedro terá insistido para que fosse o irmão D. Henrique a armar cavaleiro o condestável D. Pedro ${ }^{116}$; Soeiro da Costa, admirando as façanhas de Álvaro de Freitas, quis «seer cavaleiro de sua maão, onde o poderá seer per muy honrados Reis e grandes príncipes ${ }^{117}$.

\section{c) O ritual}

O ritual deveria ser, na grande maioria das vezes, muito mais simples do que aquele que é descrito nas fontes tratadísticas e legislativas. Fora dos campos de batalha é indiscutível a primazia da igreja, lugar de contacto com Deus. Ainda assim, parece ser uma relação direta entre os cavaleiros e o Criador, uma vez que

\footnotetext{
${ }^{112}$ CTC, cap. LRVI, págs. 253-257.

${ }^{113}$ Rákóczi István, "A Estada do Infante D. Pedro em terras húngaras e na corte do Imperador Segismundo”, Biblios, vol. LXIX (1993), págs. 79-93.

${ }^{114}$ RuI DE PINA, Chronica do senhor rey D. Affonso V, cap. CXXII, págs. 747-748. Sobre este pacto ver o artigo de Tiago Viúla de FARIA, "Pela "Santa Garrotea": Ofício cavaleiresco nas vésperas de Alfarrobeira", em XIV Colóquio de História Militar: Portugal e os conflitos militares internacionais. Actas, Lisboa, 2006, vol. II, págs. 61-86.

${ }^{115}$ Hipótese a que o próprio Galaaz adere entusiasticamente: "Senhor, se prouvesse a vós, bem ho queria seer, ca nom há cousa no mundo que tanto deseje como honra de cavalaria e seer da vossa mão ca d'outro nom no queria ser, que tanto vos ouço louvar e perçar de cavalaria que niũũ, a meu cuidar, nom podia seer covardo nem mao quem vós fezéssedes cavaleiro", em Irene FreIRE NUNES (ed.), A Demanda do Santo Graal, Lisboa, Imprensa Nacional - Casa da Moeda, 2005, págs. 20-23. 116 "Bem deu ally o Jffante dom Pedro a entender ao mundo a grande dignidade que conhecya em seu jrmão ca por mais honra teve de seu filho receber cauallarya da maão de seu tyo que de nenhuu outro principe despanha (...) lhe encomendava que sse nembrasse da ordem da cauallarya que tinha recebida e principalmente de cuja maão a rrecebera a qual cousa lhe nom era de pequeno encarrego", em $C F G$, cap. LI, págs. 191-192.

${ }^{117} C F G$, cap. LV, págs. 210-211.
} 
mesmo nos testemunhos mais antigos não se deteta a intervenção direta dos clérigos na cerimónia, para além da hipotética bênção das armas. Do conselho de passar a noite anterior em vigília, rezando e velando armas, só temos uma notícia: a de João Afonso Telo. De resto, só muito raramente é possível admitir que eventualmente se tenha realizado ${ }^{118}$. Do banho, aconselhado nas fontes transpirenaicas, nem uma menção indireta é possível detetar nos textos portugueses.

Em geral, e salvo as exceções marcadas pelo fausto próprio de manifestações de propaganda régia, a cerimónia devia ser relativamente simples. As que foram feitas antes de batalhas tiveram como palco o local onde havia de se travar o enfrentamento; as que foram efetuadas depois de uma qualquer cavalgada seriam realizadas ou naquele sítio, ou, regressando à base, num local nobre como uma igreja. Neste sentido, seriam por norma cerimónias que dispensariam um ritual demasiado complexo. Bastava a presença de algumas testemunhas e que aí houvesse um cavaleiro disposto a transmitir essa honra. Depois, aquele que queria ser armado colocava-se de joelhos. Nesse momento, segundo as Partidas e as Ordenações Afonsinas, era-lhe cingida a espada. As fontes iconográficas de além-Pirenéus mostram também que o novo cavaleiro podia ser tocado com a espada na cabeça ou nos ombros. Em Portugal, apesar de não se ter preservado uma iconografia passível de transmitir estas informações, sabe-se, por intermédio de alguns detalhes dos relatos cronísticos, que este segundo costume seria seguido ${ }^{119}$. A colocação das esporas, igualmente visível em muita iconografia, também não aparece mencionada em Portugal. É possível, contudo, que tal prática tenha sido seguida em algumas cerimónias.

\section{Conclusão}

A investidura assumiu vários significados ao longo do período abarcado por este estudo, acompanhando a evolução da instituição cavaleiresca: entre aqueles que, através da cerimónia, eram promovidos à nobreza, e aqueles que, pelo rito, procuravam materializar o cursus honorum da cavalaria. Por isso, o adubamento foi, entre os séculos XII e XV, um ato polissémico, expressando várias perspetivas. Manteve-se sempre quer uma dimensão prática, quer um intuito honorífico,

\footnotetext{
${ }^{118}$ Como na investidura dos Infantes, em Ceuta. Embora neste caso é pelo menos garantido que, se passaram a noite em vigília, não velaram armas, uma vez que a crónica refere explicitamente que, depois da missa, eles "se forom pera suas pousadas armar", em CTC, cap. LRVI, pág. 256.

${ }^{119}$ É possível detetar na cronística algumas referências a este movimento com a espada. Na investidura de Sancho de Noronha diz-se que D. Duarte de Meneses "allevamtou a maão com sua espada e fez dom Samcho cavaleiro" (CCDPM, 2 a parte, cap. XXXV, págs. 693-694); no adubamento de Soeiro da Costa diz-se de Álvaro de Freitas que "nunca sua espada tocara a cabeça de tam nobre e tam avantajado homem" (CFG, cap. LV, pág. 210).
} 
embora determinadas cronologias e circunstâncias tenham por vezes acentuado a importância de um lado em detrimento do outro.

O ritual foi influenciado em primeiro lugar pelas práticas de origem germânica. A entrega de armas marcava a promoção à idade adulta, atestava a capacidade de combater, e era uma forma de outorga de poder. Por outro lado, destaca-se igualmente a crescente importância dos símbolos cristãos, expressos, neste aspeto, por uma liturgia que não raras vezes atribuía uma importância central à igreja enquanto espaço físico ideal para receber a cavalaria, mas que suscitava também a necessidade de comunhão do cavaleiro com a organização que Deus teria gizado para a sociedade dos homens. Apesar de tudo, e pelo menos nas fontes portuguesas, os clérigos não desempenhavam uma função relevante, pelo que o ato foi sobretudo uma manifestação de piedade própria dos cavaleiros.

A complexidade da cerimónia variou em função dos homens que nela estavam envolvidos e do contexto em que foi feita. Na maioria das vezes, o rito terá sido bastante simples, não abdicando contudo da solenidade inerente ao seu significado; noutras circunstâncias, nomeadamente naquelas em que estava envolvido o poder régio, o fausto e o aparato tornavam-se símbolos de propaganda monárquica.

Por todas estas razões, o ritual aqui estudado pode ser considerado um excelente observatório para compreender muitos aspetos relacionados com a ideologia, o poder e a relação entre os grupos sociopolíticos dominantes na Idade Média.

\section{BiBLIOGRAFÍA}

A Demanda do Santo Graal, Irene Freire Nunes (ed.), Lisboa, Imprensa Nacional - Casa da Moeda, 2005.

Álvaro Lopes de Chaves, Livro de Apontamentos (1438-1489), Anastácia Mestrinho Salgado e Abílio José Salgado (eds.), Lisboa, Imprensa Nacional, 1983.

Aurell, Martin, «Chevaliers et chevalerie chez Raymond Lulle», Cahiers de Fanjeaux: Collection d'Histoire religieuse du Languedoc au XII et au début du XIV siècle, 22 (1987) págs. 141-157.

Barber, Richard, The Knight and Chivalry, Woodbridge, Boydell, 1995.

Barroca, Mário; Amaral, Luís Carlos, Teresa: a condessa-rainha, Lisboa, Círculo de Leitores, 2012.

Barthélemy, Dominique, La Chevalerie, Paris, Fayard, 2007.

Barthélemy, Dominique, «Adoubement et chevalerie dans les chansons de Roland et d'Aspremont», em De Cavaleiros e Cavalarias: por terras de Europa e Américas, Lênia Márcia Mongelli (dir.), São Paulo, Humanitas, 2012, págs. 179-189.

Branco, Maria João, D. Sancho I, Lisboa, Temas e Debates, 2010.

Brito, Pedro de, «As Cartas de Cavaleiro e Escudeiro nos Sécs. XV e XVI», Revista Lusófona de Genealogia e Heráldica, 1 (2006), págs. 207-230. 
Campos, Nuno Silva, D. Pedro de Meneses e a construção da Casa de Vila Real (1415-1437), Lisboa, Colibri/CIDEHUS, Évora, 2005.

Chancelarias Portuguesas. D. João I, João Alves Dias (ed.), Lisboa, Centro de Estudos Históricos, vol. I, t. I (1384-1385), t. II (1385), t. III (1384-1388), vol. II, t. II (1387-1402) e vol. III, t. I (1385-1410), 2004-2006.

«Chronicon Conimbricense», em Portugaliae Monumenta Historica, Scriptores, vol. I, Lisboa, 1856.

Contamine, Philippe «Points de vue sur la chevalerie en France à la fin du Moyen Âge». Francia, 4 (1976) págs. 255-285.

Cunha, Mafalda Soares, «A Nobreza Portugesa no início do Século XV: Renovação e Continuidade», Revista Portuguesa de História, XXXI: 2 (1996), págs. 219-252.

Descobrimentos Portugueses, João Martins da Silva Marques (ed.), Lisboa, Instituto Nacional de Investigação Científica, 1988, suplemento do vol. I, doc. 77, págs. 105-106.

Dias, Diogo, As Cortes de Leiria e Évora de 1472-73: Subsídios para a História Parlamentar Portuguesa, dissertação de mestrado apresentada à Universidade de Coimbra, Coimbra, 2014.

Don Juan Manuel, Libro de las Armas, em Obras Completas, José Manuel Blecua (ed.), Madrid, Gredos, 1982, págs. 127-134.

Duarte, Luís Miguel, «África», em José Mattoso (coord.), vol. I da Nova História Militar de Portugal, Manuel Themudo Barata e Nuno Severiano Teixeira (dir.), Lisboa, Círculo de Leitores, 2003, págs. 392-443.

Estoria de Dom Nuno Alvrez Pereyra, Adelino de Almeida Calado (ed.), Coimbra, Universidade de Coimbra, 1991.

Faria, Tiago Viúla de, «Pela «Santa Garrotea»: Ofício cavaleiresco nas vésperas de Alfarrobeira», em XIV Colóquio de História Militar: Portugal e os conflitos militares internacionais. Actas, Lisboa, 2006, vol. II, págs. 61-86.

Fernão Lopes, Crónica de D. Fernando, Giuliano Macchi (ed.), Lisboa, Imprensa Nacional da Casa da Moeda, 2004.

Fernão Lopes, Crónica de D. João I, M. Lopes de Almeida e A. de Magalhães Bastos (eds.), Porto, Civilização, 2 vols., 1990/91.

Fernão Lopes, Crónica de D. Pedro, Giuliano Macchi (ed.), Lisboa, Imprensa Nacional-Casa da Moeda, 2007.

Ferreira, João Paulo Martins, Entre a Consanguinidade e a Naturalidade: a movimentação da Nobreza Portuguesa entre os reinos de Portugal e Leão (1157-1230), dissertação de mestrado em História Medieval apresentada à Universidade do Porto, Porto, 2009.

Flori, Jean, «Sémantique et société medieval. Le verbe adouber et son évolution au XIIe siècle», Annales. Économies, Sociétés, Civilisations, 5 (1976), págs. 915-940.

Flori, Jean, L'Essor de la Chevalerie, Genève, Droz, 1986.

García-Fitz, Francisco, Las Navas de Tolosa, Barcelona, Ariel, 2012.

Geoffroi de Charny, A Knigt's Own Book of Chivalry, Richard W. Kaeuper e Elspeth Kennedy (eds.), Philadelphia, University of Pennsylvania Press, 2005. 
Gomes Eanes de Zurara, Crónica da Tomada de Ceuta por el rei D. João I, Francisco Maria Esteves Pereira (ed.), Lisboa, Academia das Ciências de Lisboa, 1915.

Gomes Eanes de Zurara, Crónica do Conde D. Duarte de Meneses, Larry King (ed.), Lisboa, Universidade Nova de Lisboa, 1997.

Gomes Eanes de Zurara, Crónica do Conde D. Pedro de Meneses, Maria Teresa Brocado (ed.), Lisboa, Gulbenkian, 1997.

Gomes Eanes de Zurara, Crónica dos feitos notáveis que se passaram na conquista da Guiné por mandado do infante D. Henrique, Torquato de Sousa Soares (ed.), Vol. I, Lisboa, Academia Portuguesa da História, 1997.

Gomes, Rita Costa, A Corte dos Reis de Portugal no final da Idade Média, Lisboa, Difel, 1995.

Grassotti, Hilda, Las Instituciones Feudo-Vasalláticas en León y Castilla, 2 vols., Spoleto, Centro Italiano di Studi Sull'alto Medioevo, 1969.

István, Rákóczi, «A Estada do Infante D. Pedro em terras húngaras e na corte do Imperador Segismundo», Biblios, vol. LXIX (1993), págs. 79-93.

Jean Froissart, Crónicas: duas passagens relativas a Aljubarrota, Ana Sofia Laranjinha e Mário Jorge Barroca (eds.), Fundação Batalha de Aljubarrota, 2008, págs. 35-36.

Kaeuper, Richard W., Chivalry and Violence in Medieval Europe, Nova Iorque, Oxford University Press, 1999.

Keen, Maurice, Chivalry, Yale, Yale University Press, 2005 (1 ${ }^{\text {a }}$ edição de 1984).

Livro das Leis e Posturas, Lisboa, Faculdade de Direito da Universidade de Lisboa, 1971, págs. 202-203.

Livro de Linhagens do Conde D. Pedro, José Mattoso (ed.), Lisboa, Academia das Ciências, 1980.

Livros Velhos de Linhagens: Livro Velho de Linhagens e Livro do Deão, J. Piel e José Mattoso (eds.), Lisboa, Academia das Ciências, 1980.

Livro dos Conselhos de el-rei D. Duarte, João José Alves Dias, A. H. de Oliveira Marques e Teresa Rodrigues (eds.), Lisboa, Estampa, 1982, págs. 43-49.

Martínez Ruiz, Bernabé, «La Investidura de Armas en Castilla», Cuadernos de Historia de España, vol. I-II (1944), págs. 190-221.

Marques, A. H. de Oliveira, «Cavalaria», em Joel Serrão (dir.), Dicionário de História de Portugal, Livraria Figueirinhas, vol. II, págs. 26-28.

Martins, Miguel Gomes, Guerreiros Medievais Portugueses, Lisboa, Esfera dos Livros, 2013.

Martins, Miguel Gomes, A Arte da Guerra em Portugal, Coimbra, Imprensa da Universidade de Coimbra, 2014.

Mattoso, José, «Cavalaria», em José da Costa Pereira (coord.), Dicionário Ilustrado de História de Portugal, Lisboa, Alfa, 1985, pág. 116.

Mattoso, José, Ricos-homens, Infanções e Cavaleiros, Lisboa, Guimarães Editores, 1985.

Mattoso, José, «Cavalaria», em Giulia Lanciani e Giuseppe Tavani (org.), Dicionário da Literatura Medieval Galega e Portuguesa, Lisboa, Caminho, 1993, págs. 152-154.

Mattoso, José, Identificação de um País: ensaio sobre as origens de Portugal (1096-1325), vol. I, Oposição, $5^{\text {a }}$ edição, Lisboa, Estampa, 1995. 
Mattoso, José, «Os senhores», em José Mattoso (coord.), A Monarquia Feudal, Vol. II da História de Portugal, José Mattoso (dir.), Lisboa, Estampa, 1997, págs. 148-164.

Mattoso, José, D. Afonso Henriques, Lisboa, Temas e Debates, 2011.

Mattoso, José, «A transmissão textual dos Livros de Linhagens», em Naquele Tempo: Ensaios de História Medieval, Lisboa, Círculo de Leitores/Temas e Debates, 2011, págs. 267-283.

Mattoso, José, «A coroação dos primeiros reis de Portugal», em Naquele Tempo: Ensaios de História Medieval, Lisboa, Círculo de Leitores/Temas e Debates, 2011, págs. 487-510.

Miranda, José Carlos, «Como o Rei Artur e os Cavaleiros da sua Corte demandaram o Reino de Portugal», Revista Colóquio Letras, 142 (1996), págs. 83-102.

Miranda, José Carlos, Aurs Mesclatz ab Argen: sobre a primeira geração de trovadores galegoportugueses, Porto, Edições Guarecer, 2004.

Monteiro, João Gouveia, A Guerra em Portugal no Final da Idade Média, Lisboa, Notícias, 1998.

Monteiro, João Gouveia, «De D. Afonso IV (1325) à batalha de Alfarrobeira (1449): os desafios da maturidade», em José Mattoso (coord.), vol. I da Nova História Militar de Portugal, Manuel Themudo Barata e Nuno Severiano Teixeira (dir.), Lisboa, Círculo de Leitores, 2003, págs. 163-287;

Oliveira, Luís Filipe, «Os cavaleiros de Carneiro e a herança da cavalaria vilã na Estremadura. Os casos de Arruda e de Alcanede», Medievalista [em linha], 1 (2005), disponível em: $<$ http://www2.fcsh.unl.pt/iem/medievalista/MEDIEVALISTA1/medievalista-cavaleiros. htm> [Consulta: 10/10/2014].

Ordenações Afonsinas, fac-simile da edição feita na Real Imprensa da Universidade de Coimbra em 1792, Lisboa, Fundação Calouste Gulbenkian, 1998, título LXIII, págs. 368-372.

Palacios Martín, Bonifacio, «Investidura de Armas de los Reyes Españoles en los siglos XII y XIII», Gladius, Exemplar dedicado às Actas do I Simpósio Las Armas en la Historia (siglos X-XIV), volume especial (1988), págs. 153-192.

Palacios Martín, Bonifacio, «La recepcíon de los valores caballerescos por la monarquia castellano-leonesa», Codex Aquilarensis: cadernos de investigación del monasterio de Santa María la Real, 13 (1997/98), págs. 88-95.

Partida Segunda de Alfonso X El Sabio, Manuscrito 12794 de la B. N., Aurora Juárez Blanquer e Antonio Rubio Flores (eds.), Granada, Impredisur, Título XXI, págs. 184-187.

Pilbrow, Fionn, «The Knigths of the Bath: Dubbing to Knighthood in Lancastrian and Yorkist England» em Heraldry, Pageantry and Social Display in Medieval England, Peter Cross e Maurice Keen (eds.), Boydell, 2002, págs. 195-218.

Pontes, Luís Filipe, Do mundo da corte ao mundo da memória - subsídios para o estudo da mentalidade cavaleiresca da nobreza portuguesa, 1400-1521, dissertação de mestrado apresentada à Universidade Nova de Lisboa, Lisboa, 2008.

Quintanilla Raso, Maria Concepción, Nobleza y Caballería en la Edad Media, Madrid, Arcos Libros, 1996.

Raimundo Llull, Livro da Ordem de Cavalaria, Artur Guerra (ed.), Lisboa, Assírio e Alvim, 2012.

Rodríguez Velasco, Jesús, «De oficio a estado. La caballería entre el Espéculo y las Siete Partidas», Cahiers de Linguistique Hispanique Médiévale, 18-19 (1993), págs. 49-77. 
Rodríguez Velasco, Jesús, Ciudadanía, Soberanía Monárquica y Caballería: Poética del Orden de Caballería, Madrid, Akal, 2009.

Rui de Pina, Crónicas de Rui de Pina, M. Lopes de Almeida (ed.), Porto, Lello \& Irmãos, 1977.

Sáiz Serrano, Jorge, Caballeros del rey: nobleza y guerra en el reinado de Alfonso el Magnánimo, Valência, Universitat de València, 2008.

Saul, Nigel, For Honour and Fame: Chivalry in England, 1066-1500, London, Pimlico, 2012.

Sottomayor-Pizarro, José Augusto de, Linhagens Medievais Portuguesas (1279-1325): Genealogias e Estratégias, dissertação de doutoramento apresentada à Universidade do Porto, Porto, 1997, 2 vols.

Sottomayor-Pizarro, José Augusto de, «De e para Portugal: a circulação de nobres na Hispânia Medieval (séculos XII a XV)», Anuario de Estudios Medievales, vol. 40, núm. 2 (2010), págs. 889-924.

Sousa, Armindo de, «Nobres», em José Mattoso (coord.), A Monarquia Feudal, vol. II da História de Portugal, José Mattoso (dir.), Lisboa, Estampa, 1997, págs. 369-389.

Stevenson, Katie, Chivalry and the practices of Knighthood in Scotland, 1421-1513, Cambdrige University Press, 2006.

Tácito, La Germanie, Jacques Perret (ed.), Paris, Société d’Édition Les Belles Lettres», 1983, págs. 78-80.

Taylor, Craig, «Henry V, Flower of Chivalry», em Henry V: New Interpretations, Gwily Dodd (ed.), York, York Medieval Press, 2013, págs. 217-247.

Ventura, Leontina, A Nobreza de Corte de D. Afonso III, dissertação de doutoramento apresentada à Universidade de Coimbra, Coimbra, 1992, vol. II.

Ventura, Leontina, «Nobreza - da Guerra à Corte», em Maria Helena da Cruz Coelho e Armando Luís de Carvalho Homem (coord.), Portugal em Definição de Fronteiras, vol. III da Nova História de Portugal, Joel Serrão e A. H. de Oliveira Marques (dir.), Lisboa, Presença, 1996, págs. 206-224.

Viana, Mário, «Os Cavaleiros de Santarém na segunda metade do Século XIII», em Categorias Sociais e Mobilidade Urbana na Baixa Idade Média, Lisboa, Colibri/CIDEHUS, 2012, págs. 61-81.

Werner, Karl Ferdinand, Naissance de la Noblesse, Paris, Fayard, 2010. 